\title{
Togo: Staff-Monitored Program
}

This paper on the Staff-Monitored Program for Togo was prepared by a staff team of the International Monetary Fund as background documentation for the periodic consultation with the member country. It is based on the information available at the time it was completed on December 21, 2006. The views expressed in this document are those of the staff team and do not necessarily reflect the views of the government of Togo or the Executive Board of the IMF.

The policy of publication of staff reports and other documents by the IMF allows for the deletion of market-sensitive information.

To assist the IMF in evaluating the publication policy, reader comments are invited and may be sent by e-mail to publicationpolicy@imf.org.

Copies of this report are available to the public from

International Monetary Fund • Publication Services

700 19th Street, N.W. • Washington, D.C. 20431

Telephone: (202) 6237430 • Telefax: (202) 6237201

E-mail: publications@imf.org • Internet: http://www.imf.org

Price: $\$ 18.00$ a copy

\section{International Monetary Fund Washington, D.C.}





\section{INTERNATIONAL MONETARY FUND}

\section{TOGO}

\section{Staff-Monitored Program}

Prepared by the African Department

(In consultation with other departments)

Approved by Sharmini Coorey and Adnan Mazarei

December 21, 2006

Objectives: A mission team visited Lomé during October 23-November 4, 2006 to discuss economic developments and policies and reach understandings on a Staff-Monitored Program (SMP) for the period October 1, 2006 to June 30, 2007.

Country representatives: The mission met with President Faure Gnassingbé, Prime Minister Yawovi Agboyibo, Finance Minister Boukpessi, National Director of the Central Bank for West African States (BCEAO) Gbeasor, and other senior officials. It also met with parliamentarians, banks, trade associations, donors, and representatives of the regional offices of the BCEAO and West African Economic and Monetary Union (WAEMU) Banking Commission.

Mission team: The mission team comprised Mr. Mumssen (head), Mr. Rosa, Mr. Gijón-Spalla (all AFR), and Ms. Mitchell Casselle (MCM). Mr. Sacerdoti (AFR), the previous mission chief, joined the mission for the first week. Mr. Yao, the Fund's Resident Representative for Togo, and Mr. Bah, from the Fund's Office of the Executive Director for Togo, participated in the discussions. The mission was joined by staff representatives of the World Bank and the African Development Bank.

Article IV consultation: The last Article IV consultation was completed on May 8, 2006. The Executive Board also considered an Ex Post Assessment of Longer Term Program Engagement at that time.

Use of Fund resources: The last Fund arrangement expired in June 1998. Togo is current on debt service to the Fund. Approval of a new PRGF arrangement would require: (i) fully satisfactory performance under the SMP through the end of June 2007; (ii) financing assurances from donors; and (iii) understandings on external arrears clearance.

Exchange system: Togo has accepted the obligations of Article VIII, Sections 2, 3, and 4. Togo shares a common currency (CFA franc), pegged against the euro, with other WAEMU members. The BCEAO conducts monetary and exchange rate policies for the region. Banks are supervised by the WAEMU Banking Commission. 
Contents Page

Executive Summary. 3

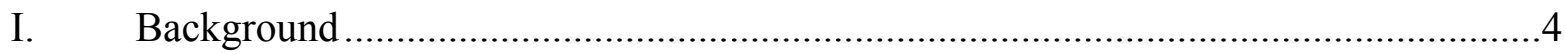

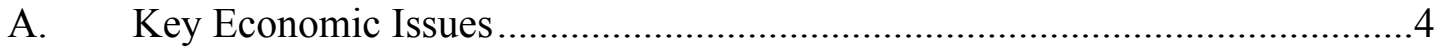

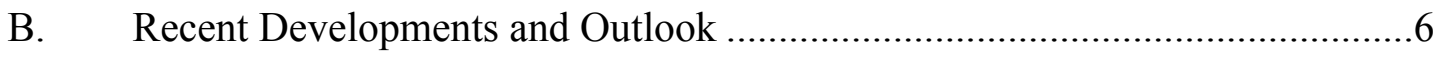

C. Reengagement with the Fund..............................................................

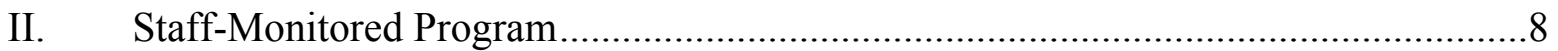

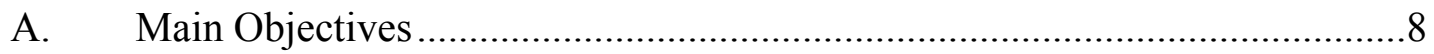

B. Fiscal Policies and Reforms............................................................. 10

C. Banking Sector.......................................................................................... 12

D. Public Enterprise Reform....................................................................14

E. Medium-Term Poverty Reduction and Growth Strategy .............................14

F. Program Monitoring and Risks ............................................................. 15

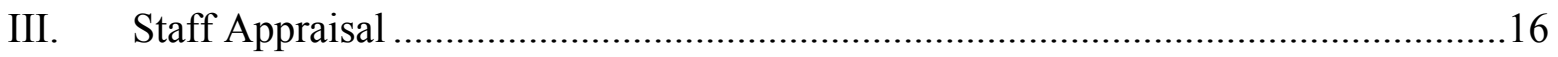

Tables

1. Selected Economic and Financial Indicators, 2003-07.....................................19

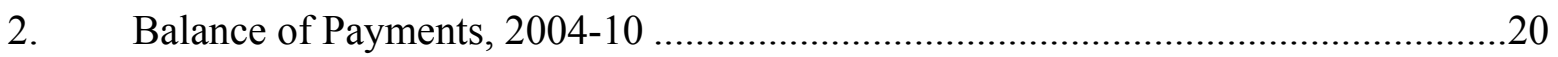

3. Financial Operations of the Central Government, 2005-07 ...................................21

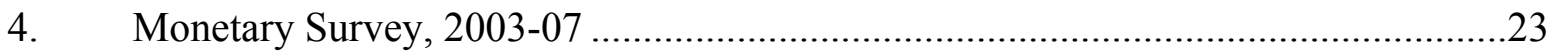

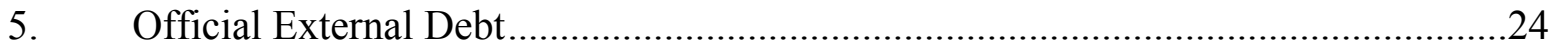

Appendices

I. Relations with the Fund ...............................................................................25

II. Relations with the World Bank .........................................................................28

Attachment I

Letter of Intent and Memorandum of Economic and Financial Policies

Table 1. Quantitative Benchmarks Under the Staff-Monitored Program,

October 1, 2006-June 30, 2007 .36

Table 2. Structural Benchmarks Under the Staff-Monitored Program,

October 2006-June 2007

Attachment II

Technical Memorandum of Understanding . 


\section{EXECUTIVE SUMMARY}

Following a prolonged economic decline and disengagement from donors, Togo has initiated political and economic reforms. A recent multiparty agreement and the formation of a national unity government have paved the way for holding the first free parliamentary elections in decades in mid-2007. Key donors are considering resuming assistance. The government intends to launch economic reforms in parallel with the political reform process.

To revive economic growth, Togo must address a legacy of political instability, governance problems, weak state-owned enterprises and banks, and excessive public debt. Weak expenditure management and lack of donor financing have squeezed social spending and contributed to chronic accumulation of domestic and external arrears and nonexecution of budgets. Debt is well above the HIPC threshold. Several banks are burdened by large nonperforming loans to the cotton and phosphate sectors and remain heavily undercapitalized despite recent budgetary injections. Cotton exports have plummeted due to arrears to farmers, adverse terms of trade, and real exchange rate appreciation, holding back a nascent economic recovery and raising external imbalances. Inflation remains subdued.

During the recent mission, the staff and the authorities reached understandings on a nine-month SMP, primarily designed to support macroeconomic stability. This followed the completion of a large set of prior actions to address governance and transparency concerns in the fiscal, cotton, and banking areas. The SMP aims to: (i) support the preparation of a realistic 2007 budget, with a moderate primary adjustment; (ii) anchor budget execution in a pre-election period; (iii) strengthen fiscal governance, especially on expenditure management; (iv) initiate urgent banking sector reforms; and (v) prepare for state-owned enterprise reforms. During the SMP, the authorities intend to update Togo's IPRSP, set up a program monitoring mechanism, and reengage with donors, whose technical and financial assistance will be crucial for medium-term prospects.

After the SMP, the authorities intend to request a PRGF arrangement, which would be the first since 1998 and could pave the way for HIPC debt relief. Staff noted that Board approval will require (i) fully satisfactory SMP performance; (ii) financing assurances from donors; and (iii) understandings on arrears clearance, which will require substantial coordination with donors and creditors, in particular to resolve World Bank arrears.

Program risks are high. The SMP covers a politically charged period, with possibly significant pressures on the budget. A disruption of the political reform process would likely prevent the resumption of donor assistance. The weak financial positions of state-owned companies and banks pose additional risks. Togo also remains exposed to commodity price swings, electricity shortages, and changes in regional conditions. Notwithstanding these risks, the program could help preserve macroeconomic stability and unlock external assistance. 


\section{BACKGROUND}

\section{A. Key Economic Issues}

\section{Togo has been in economic decline and cut off from donor support for much of} the past decade. Real per capita GDP declined by almost 1 percent a year on average between 1990 and 2005. Togo's last program with the Fund ended in 1998. Performance under a six-month SMP in 2001 was too weak to move to a Poverty Reduction and Growth Facility (PRGF) arrangement. The EU suspended its aid to Togo in 1998 because of concerns over its political process and human rights record. The World Bank suspended its lending operations in 2002, when Togo started running up arrears to the Bank. The economic decline has reduced living standards and deepened poverty.
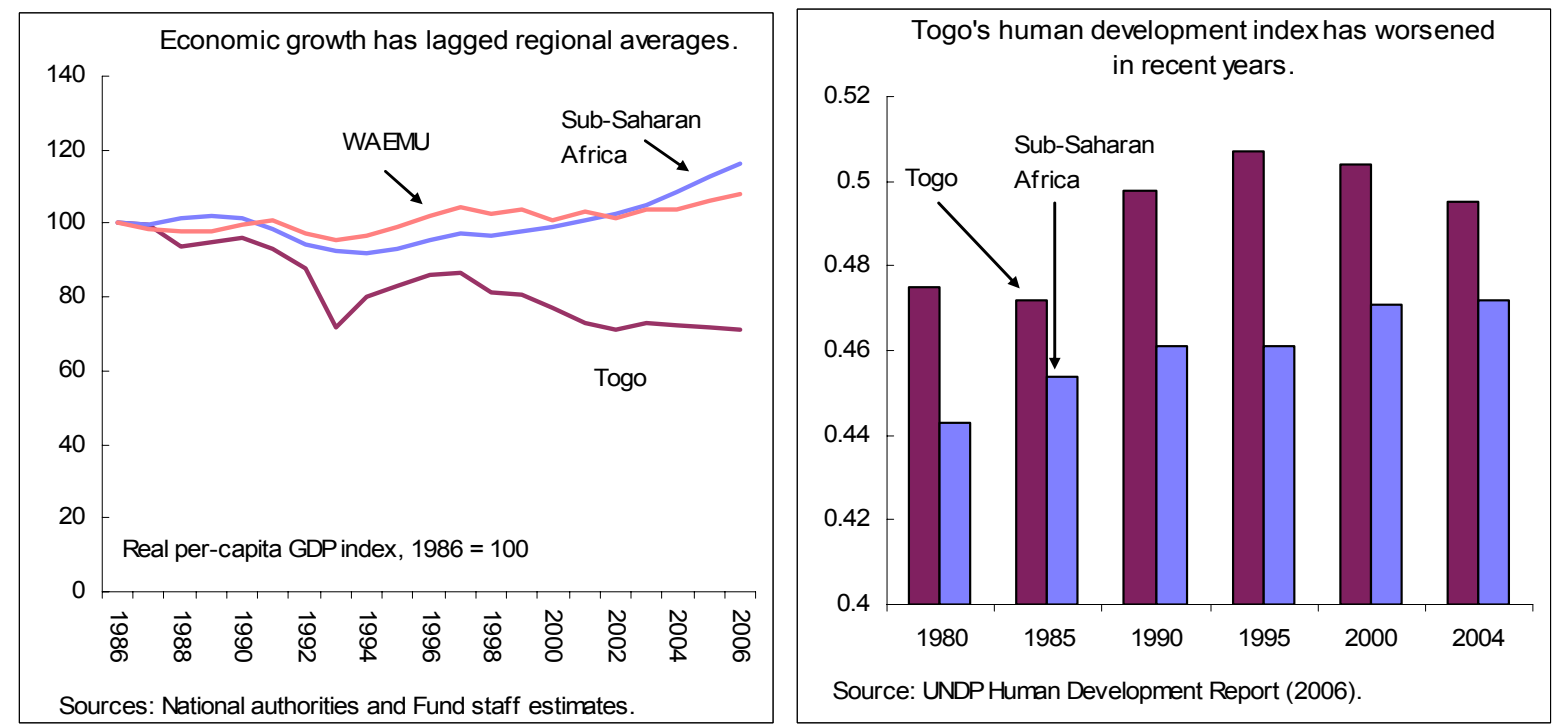

2. Political turmoil, governance problems, and poor performance by state-owned enterprises have been at the heart of Togo's economic problems. Political conflict and civil strife during a turbulent transition to multiparty democracy have weakened institutional capacity and economic policy implementation.

Governance problems have undermined budget execution, access to foreign aid, the performance of public enterprises (which dominate the export sector), and the viability of the financial sector. Adverse terms of trade developments, real exchange rate appreciation, poor internal pricing policies, and weak management have fuelled losses in public enterprises,

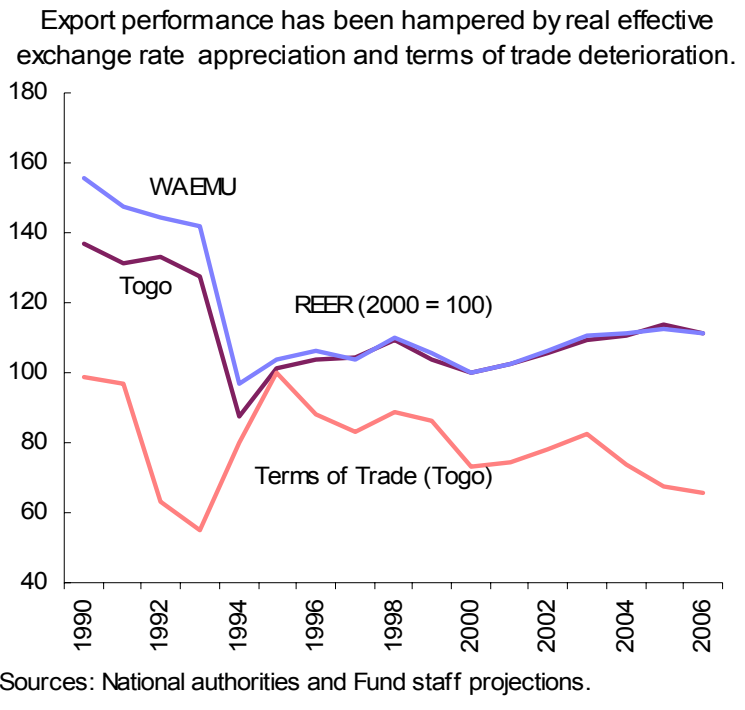
especially in the cotton and phosphate 
sectors, which accumulated large arrears to farmers, suppliers, and banks. These quasi-fiscal deficits have increasingly spilled into the budget and government debt.
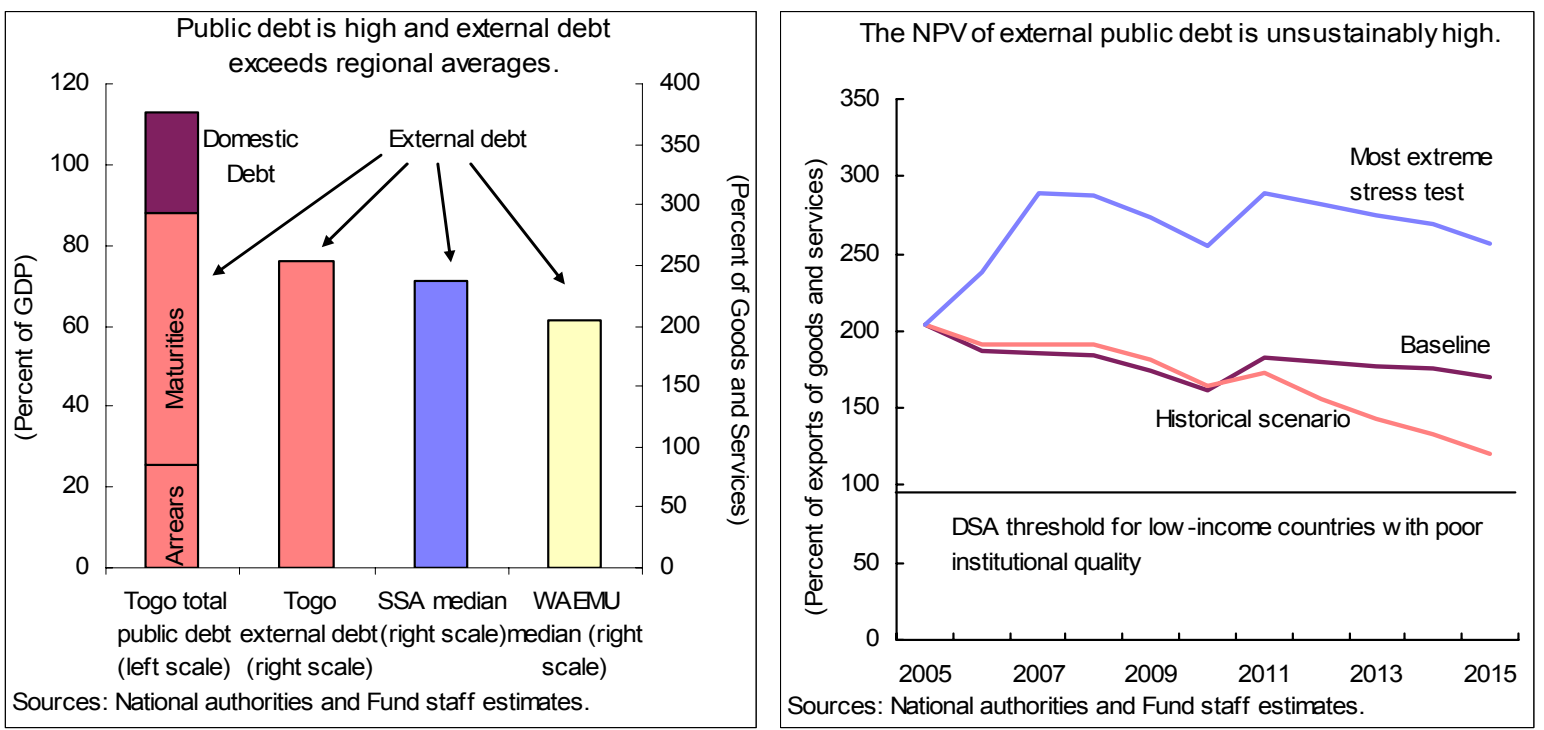

3. Public debt has been unsustainably high for decades and external arrears have grown rapidly. Total public debt was almost 115 percent of GDP in 2005, about a quarter of which was domestic. The net present value of external public debt was about twice the debt sustainability threshold for low-income countries with poor institutional quality. A recent debt sustainability analysis showed that Togo is in debt distress and particularly vulnerable to export shocks.

\section{Weak expenditure management and lack of donor financing have squeezed} social sector resources and contributed to chronic arrears accumulation and the nonexecution of budgets. The suspension of foreign aid has imposed a tight financing constraint in recent years, reducing the scope for spending on health, education, and critical infrastructure. Higher revenue collections, a freeze on civil servant salaries and promotions, and cuts in capital expenditures have eased some of the budget pressures and kept the primary and overall deficits well below regional averages. However, lack of control over discretionary expenditure, including on elections and unclassified sovereign needs, have resulted in mounting domestic and external arrears. Faced with political pressures and loss of confidence from suppliers, the government has increasingly resorted to exceptional procedures for spending on goods and services, without appropriate ex-ante controls and ex-post monitoring, eroding the

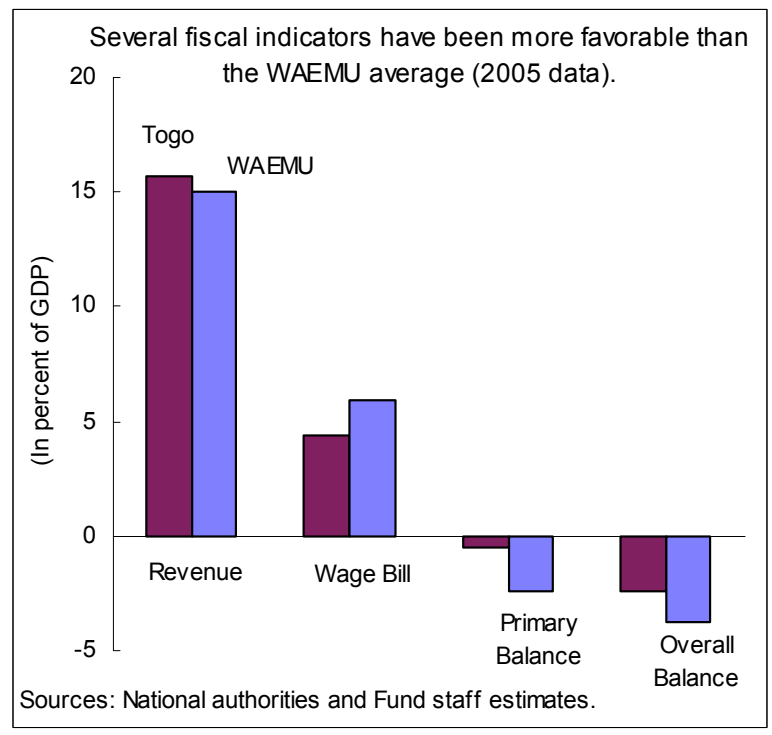


credibility of the budgetary process.

5. The banking sector has the highest share of nonperforming loans (NPLs) in the WAEMU, mainly reflecting past directed lending to the cotton and phosphate sectors. The two largest state-owned banks have suffered from debt defaults by the state-owned cotton company SOTOCO, the state-controlled phosphate company OTP, and the largest private cotton ginnery SICOT, whose combined debt to the banking sector amounts to $6 \frac{1}{4}$ percent of GDP and for more than half of banking system NPLs. Despite partial recapitalizations by the government, these banks remain severely undercapitalized and unprofitable. One large bank has experienced liquidity problems and not complied with several prudential norms. By contrast, some other private banks have grown rapidly, reflecting ample liquidity in the WAEMU area and Togo's growing role as a regional trade hub. Total banking deposits grew at an average annual rate of $12 \frac{1}{2}$ percent in 2002 06.

\section{B. Recent Developments and Outlook}

6. The political environment has improved since 2005, and the authorities have stepped up their efforts to reengage with donors. A newly elected government assumed office in April 2005 following the death of the long-time President Eyadéma. In

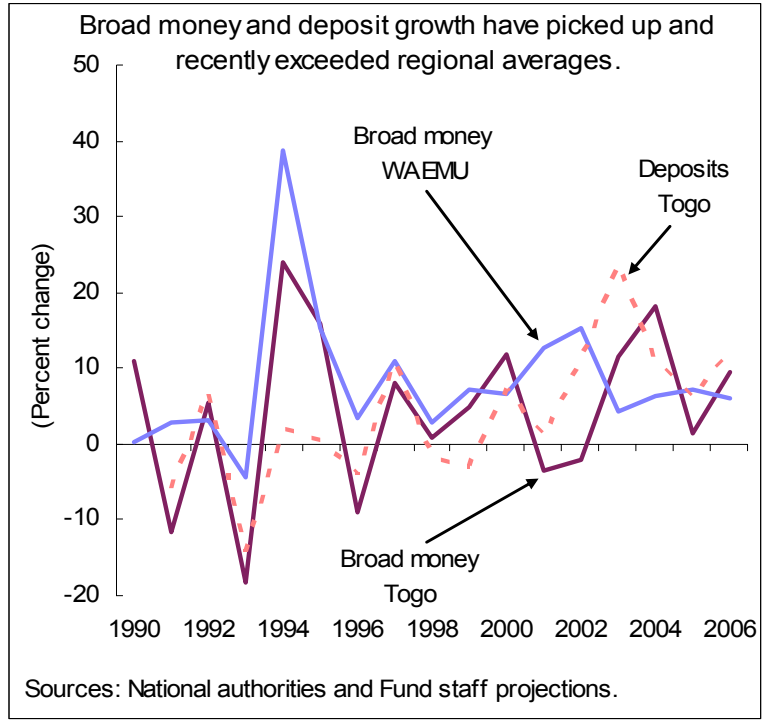
August 2006, the ruling party and all opposition parties signed an agreement that defines a framework for parliamentary elections envisaged for mid-2007. A new prime minister was appointed and a national unity government formed in September. These events are expected to lead to the resumption of large-scale EU assistance. France has pledged $€ 5$ million in emergency aid. 

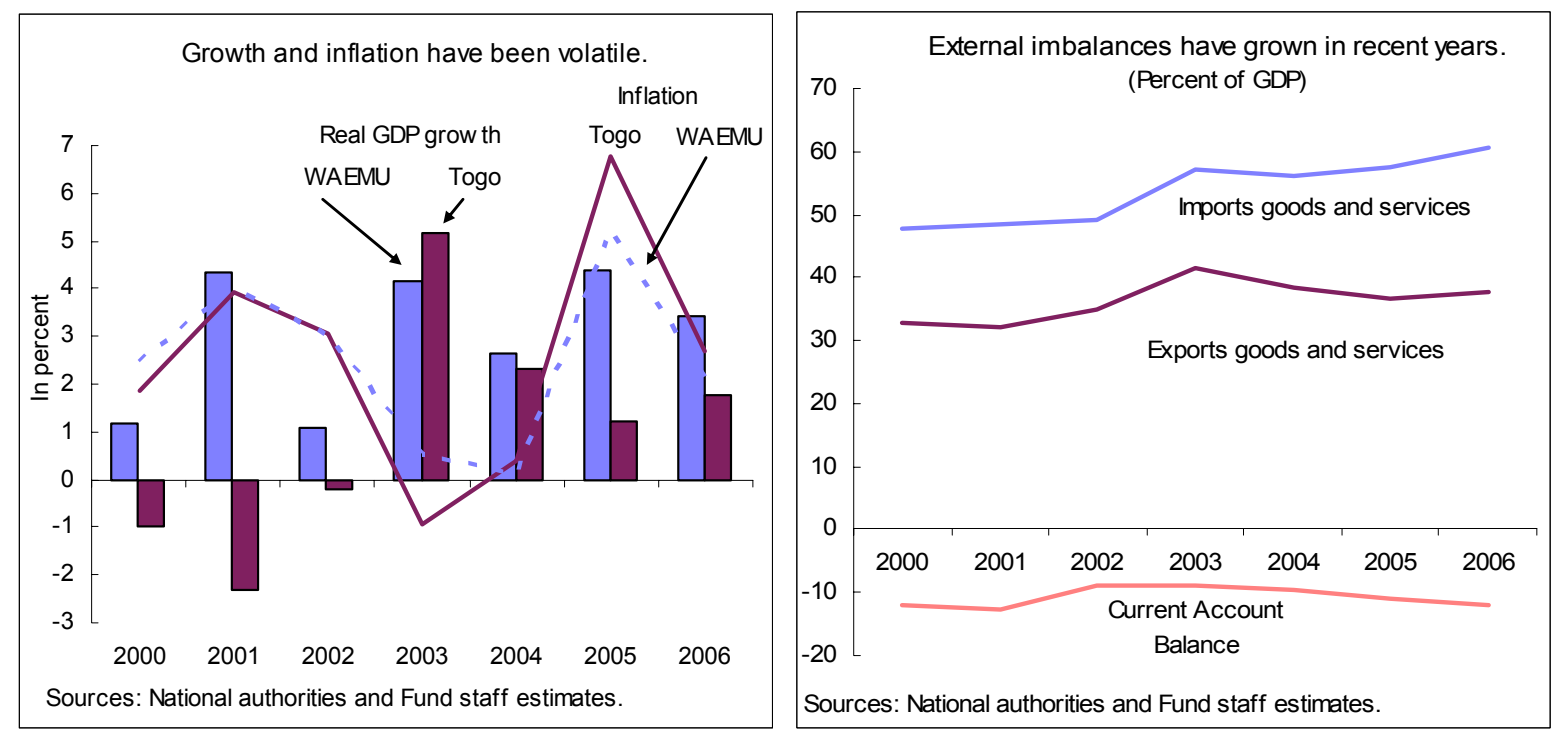

7. A modest economic recovery has coincided with widening external imbalances. Real GDP growth is projected to reach 13/4 percent in 2006 (Table 1), mainly driven by transport services linked to the Port of Lomé and Togo's increasing role as a regional trade hub. Services growth has offset the impact of the deepening crisis in the cotton sector, which has been exacerbated by poor weather conditions. Cotton output is expected to fall by 30 percent this year, to only about one-quarter the 2001-05 average. Cotton farmers have largely shifted to other crops because of low cotton prices, the removal of fertilizer subsidies, and SOTOCO's failure to pay them for the 2004/05 harvest. Inflation, after spiking in 2005, is projected to return to the low single digits in 2006, reflecting a moderation in food prices across the region. The current account deficit is expected to rise to $123 / 4$ percent of GDP in 2006, as a result of higher oil prices and lower exports, the latter partly reflecting the sharp drop in cotton production (Table 2). Capital inflows, including the five-year treasury bond issued on the regional market earlier this year, are expected to increase in 2006 and help keep gross international reserves at about three months of imports. Growth is projected to increase further in 2007 as the decline of the cotton sector is expected to be halted as output prices stabilize and the government settles SOTOCO's arrears.

\section{Reengagement with the Fund}

8. The authorities requested an SMP over a year ago, but initial discussions proved difficult. The authorities and staff failed to reach agreement on the 2006 budget, reflecting disagreements over the planned regional bond issue and repayment of arrears to cotton farmers. Staff was also concerned about the lack of information on the financial status of the banking sector and about possible governance problems related to the use of SOTOCO's export receipts in 2004/05, sizable extrabudgetary operations, and the existence of multiple government accounts outside the Treasury's control.

9. Implementation of prior actions has demonstrated the authorities' commitment to address governance concerns and reengage with the Fund. Prior actions focused on key governance and transparency concerns in the fiscal area and the state-dominated cotton 
sector, and on adequate monitoring of banking sector risks (Box 1). Having completed these measures, the authorities reached understandings with staff on a nine-month SMP to allow Togo to build a track record for a possible PRGF arrangement. ${ }^{1}$ The timing of the SMP (October 1, 2006-June 30, 2007) could allow resumption of IMF financing in the second half of 2007, at a time when several large donors and creditors are expected to reengage in the wake of the planned elections.

\section{Staff-Monitored Program}

\section{A. Main Objectives}

10. The authorities emphasized their commitment to continue ongoing political reforms in parallel with launching economic reforms and reengaging with donors. They noted that Togo had successfully implemented strong reforms after independence, but, political conflict, disengagement from donors, and ineffective public sector staffing and wage policies have steadily undermined economic policy and institutional capacity. They considered the SMP an opportunity to establish a track record of sound policy implementation and reengage with key development partners. Successful implementation of the SMP would also help build a track record for a PRGF arrangement, which in turn could pave the way for comprehensive debt relief under the HIPC initiative and MDRI.

\section{The SMP focuses on macroeconomic stability in a potentially volatile pre-}

election period. Specifically, it should help anchor prudent fiscal policies in the run-up to the first free parliamentary elections in decades planned for June 2007 and as losses of stateowned banks and enterprises risk spilling over into the budget. The authorities also plan to initiate preparatory work on a broader medium-term reform program during the SMP, although implementation would be possible only after political stabilization, capacity enhancement, and donor reengagement.

\section{Improving fiscal governance will be a central objective of the SMP, in addition} to initiating reforms of state-owned banks and enterprises. These structural reforms should help bolster economic stability, pave the way for broader reforms, and facilitate reengagement with the donor community. Progress on fiscal governance will also be needed to ensure that budgetary planning, execution, and monitoring can support an eventual PRGF arrangement.

\footnotetext{
${ }^{1}$ Given Togo's long disengagement from the Fund, the 9-month SMP period is relatively short, but takes into account the completion of many structural reforms as prior actions over the last six months.
} 


\section{Box 1. Prior Actions for the Staff-Monitored Program}

\begin{tabular}{cc}
\hline Prior actions & Comments \\
\hline
\end{tabular}

\section{Cotton sector}

1. Complete audit of arrears owed to cotton farmers.

2. Launch a financial audit of the cotton company, including on revenues of cotton sales and their use.

3. Adopt a schedule of repayment to farmers, in line with understandings with Fund staff, and initiate repayments.

Done. An audit by an international company established SOTOCO's arrears to cotton farmers at CFAF 23 billion (about 2 percent of GDP). Authorities provided data on SOTOCO's use of the 2004/05 cotton export proceeds. A planned financial audit (see point 2) will report all the revenues coming from the sale of cotton during the last three campaigns as well as their use.

Done. International competitive tender launched in July 2006, based on Terms of References drafted by the World Bank. Auditor to be selected on a noobjection basis by the French Development Agency (ADF). Completion of the financial and strategic audits is structural benchmark under the SMP.

Done. First payment of CFAF 6 billion made in July 2006. Second and third payments (CFAF 6 billion each) scheduled for December 2006 and April 2007. . The final payment of CFAF 5 billion is envisaged for September 2007, conditional on identifying external financing.

\section{Fiscal governance}

4. Deposit all proceeds from the WAEM bond at the BCEAO.

5. Review all accounts of government agencies with the banking system and decide which ones will be maintained.

6. Close accounts of the tax and customs administration outside the treasury's control and develop appropriate monitoring mechanisms for accounts that will be maintained.

7. Submit to parliament a draft 2007 budget, including a budget execution projection for 2006 that is in line with understandings with the staff.

8. Submit to staff monthly fiscal outturns within two months after the end of each month.

9. Begin weekly transfer of tax and customs revenue to the treasury.

\section{Banking system}

10. Provide staff with updated reports on bank liquidity for mid-October.

11. Put in place contingency plans for dealing with possible liquidity distress that have been agreed between the staff and the authorities.
Done. Proceeds were deposited in a treasury subaccount at the BCEAO, which can be accessed for capital spending, arrears repayment, and other expenditures specified by the Minister of Finance, but not for regular treasury operations.

Done. The authorities have reviewed all commerical bank accounts of public agencies and confirmed that (i) the accounts of tax and customs administration have been closed (see point 6 ), and (ii) other government agencies retain only project accounts.

Done. Customs and tax revenues of about 2 percent of GDP had reportedly been diverted to finance the security forces and the ruling party's presidential election campaign in 2005 and early 2006. According to the government, this practice stopped in May 2006 when the military personnel heading the customs administration were replaced by civilians and the associated bank accounts at $\mathrm{BTCl}$ closed.

Done. The draft 2007 budget law was submitted to parliament on December 11, 2006. It includes 2006 projections that are broadly in line with understandings with the staff. The government elaborated on the use of the regional bond proceeds during the parliamentary discussion. The draft 2007 budget is broadly consistent with understandings reached with IMF staff. Quantitative targets under the SMP for the first half of 2007 are consistent with the full-year objectives under the draft budget.

Done. The end-August fiscal accounts were provided to staff in late October 2006. Preliminary figures for end-September were sent to staff in late November 2006

Done. Tax administration transfers revenues to treasury on a weekly basis, and customs administration at least twice a week.

Done. Authorities provided detailed information on banks' liquidity and financial situation between end-year 2005 and September 2006. Regular reporting is included as a continuous structural benchmark under the SMP.

Done. In case of liquidity pressures on a bank, the regional supervisor can rely on voluntary interbank liquidity support ("solidarité de la place") and the BCEAO can provide liquidity for rediscountable assets, although, in line with best practice, it will not act as lender-of-last-resort for insolvent banks. The Minister of Finance has agreed with Fund staff on general principles of contingency plans, including: (i) a mechanism for monitoring banks' liquidity; (ii) an ongoing assessment by the regional supervisor of banks' progress in strengthening their financial position; (iii) a menu of options for dealing with different types of liquidity pressure; (iv) linking additional budgetary support to the implementation of supervisory recommendations; and (v) an agreement to keep Fund staff informed. Future technical assistance missions by IMF banking experts will follow up on details. 


\section{The government's Letter of Intent (LOI) and Memorandum of Economic and Financial Policies (MEFP) detail key steps under the SMP (Attachment I):}

- Improving fiscal management and budgetary transparency, by adopting and implementing a realistic 2007 budget, underpinned by structural measures to strengthen fiscal governance, in particular expenditure management;

- $\quad$ Addressing banking sector problems, by better monitoring troubled banks, adopting contingency plans, implementing the recommendations of the regional supervisor, and designing a comprehensive bank restructuring strategy;

- $\quad$ Preparing for state-owned enterprise reforms, by auditing the cotton and phosphate companies, regularizing cotton arrears, and initiating work on restructuring and privatization strategies, in coordination with the World Bank; and

- $\quad$ Setting up a program monitoring mechanism that enables the authorities to adjust their policies to economic and financial developments in a timely manner.

Togo: Selected Economic and Financial Indicators, 2004-07

\begin{tabular}{|c|c|c|c|c|}
\hline \multirow[b]{3}{*}{ Real GDP (percent change) } & 2004 & 2005 & 2006 & 2007 \\
\hline & \multicolumn{2}{|c|}{ Est. } & \multicolumn{2}{|c|}{ Projections } \\
\hline & 2.3 & 1.2 & 1.8 & 2.9 \\
\hline Consumer prices (annual average, percent change) & 0.4 & 6.8 & 2.7 & 2.9 \\
\hline Broad money (M2, percent change) & 18.3 & 1.4 & 9.7 & 2.4 \\
\hline Fiscal revenue, excluding grants (percent of GDP) & 16.8 & 15.7 & 16.1 & 16.6 \\
\hline Domestic primary balance (percent of GDP) & 3.2 & -0.5 & -1.7 & -0.4 \\
\hline Current account balance (percent of GDP) & -9.5 & -11.1 & -12.1 & -12.1 \\
\hline External public debt (percent of GDP) & 86.3 & 88.0 & 77.4 & 73.9 \\
\hline
\end{tabular}

Sources: Togolese authorities; and Fund staff estimates and projections.

\section{B. Fiscal Policy and Reform}

14. The execution of the 2006 budget is on track in most areas, and the accumulation of domestic arrears has been halted. Revenue collection during the first eight months was consistent with the full-year budget target of 16 percent of GDP, with strong customs collections and recovery of tax arrears offsetting weak nontax revenues (Table 3). Total expenditures are also expected to be broadly in line with the budget, although their composition will differ in several areas. Specifically, in line with Fund staff recommendations, the authorities have paid part of SOTOCO's arrears to cotton farmers (Box 1) and spread the bond-financed domestic investment program over two years instead of one. Assuming expenditure restraint in the fourth quarter (see below), the primary deficit 
for 2006 should be about $13 / 4$ percent of GDP, broadly in line with the 2006 budget objective after factoring out the repayment of SOTOCO's arrears. ${ }^{2}$

\section{The authorities acknowledged that the growing spending pressures will need to}

be contained. The wage bill is projected to increase sharply in 2006 and 2007 after a 10-year freeze on civil servant salaries was lifted and contractual teachers were converted into civil servants. ${ }^{3}$ The 2006 budget also includes an additional subsidy of almost $3 / 4$ percent of GDP to cover a growing deficit of the state-owned pension system (as an increasing number of civil servant reach retirement age). The recent regional bond issue (about 3 percent of GDP) has started to finance long-delayed investment in critical infrastructure, schools, hospitals, water, and sanitation. Given these anticipated and justifiable expenditure pressures, the staff stressed the need to rein in discretionary spending, noting that the entire budget allocation for goods and services in 2006 had been spent by end-August once other spending (without budget line identification) is included (Table 3 ). The authorities noted that they had partly addressed this problem by closing bank accounts used for extrabudgetary spending and by replacing the heads of customs and tax administration in May 2006. However, more than half of all goods and services spending continue to be executed through exceptional and accelerated procedures without prior budget line identification. The authorities agreed to reduce such discretionary spending in the last quarter of 2006, including by terminating new spending commitments at end-November and new payments orders by end-December (a structural benchmark under the SMP).

16. The authorities are committed to execute a realistic budget for 2007 that anchors macroeconomic stability in an election year. They have submitted a draft budget to parliament that would result in a reduction of the primary deficit by about $1 \frac{1}{4}$ percentage points of GDP, to about $1 / 2$ percent of GDP. The adjustment is based on continued reforms to strengthen revenue collection (by $1 / 2$ percentage point of GDP) combined with a sharp reduction in discretionary spending on goods and services, including unclassified spending through exceptional procedures (by about 1 percentage point of GDP). The government intends to retain sufficient contingent resources for possible bank restructuring and debt service $^{4}$ (of about $3 / 4$ percentage points of GDP). The authorities intend to make spending in

\footnotetext{
${ }^{2}$ Repayment of SOTOCO's arrears to cotton farmers was not included in the 2006 budget. It is classified as a subsidy, raising the primary deficit by about 1 percent of GDP.

${ }^{3}$ The civil service salary structure had been frozen since 1996 and step-adjustments for length of service were suspended in 2000. Hiring was sharply curtailed and many teachers were employed as contractuals with lower salaries and benefits. As a result, the wage bill declined from 56 percent of revenues in 1995 to 28 percent in 2005, well below the WAEMU criterion of 35 percent. This made it difficult to keep qualified civil servants, including in education. In 2006, as envisaged in the budget, accumulated step adjustments to civil servant salaries were retroactively implemented and 9,000 contractual teachers were converted into civil servants, with higher salaries and child allowances.
}

${ }^{4}$ The SMP covers a period during which arrears to external creditors will continue to accumulate. This is not unusual for highly indebted (HIPC eligible) countries as it is generally recognized that these countries cannot service their debt without external assistance and debt rescheduling. The 
the second half of 2007 contingent on identifying external sources to cover a projected financing gap of $1 \frac{1}{4}$ percent of GDP. ${ }^{5}$ The SMP targets for the first two quarters are in line with these objectives (Table 3 and MEFP Table 1).

\section{Continued progress on fiscal} governance will be critical to implement the budget. Following recent measures to bolster fiscal transparency and curtail extrabudgetary spending (Box 1), the authorities plan to press ahead with further structural reforms (paragraph 12 and Table 2 of the MEFP, Attachment I). These include structural benchmarks to audit domestic debt

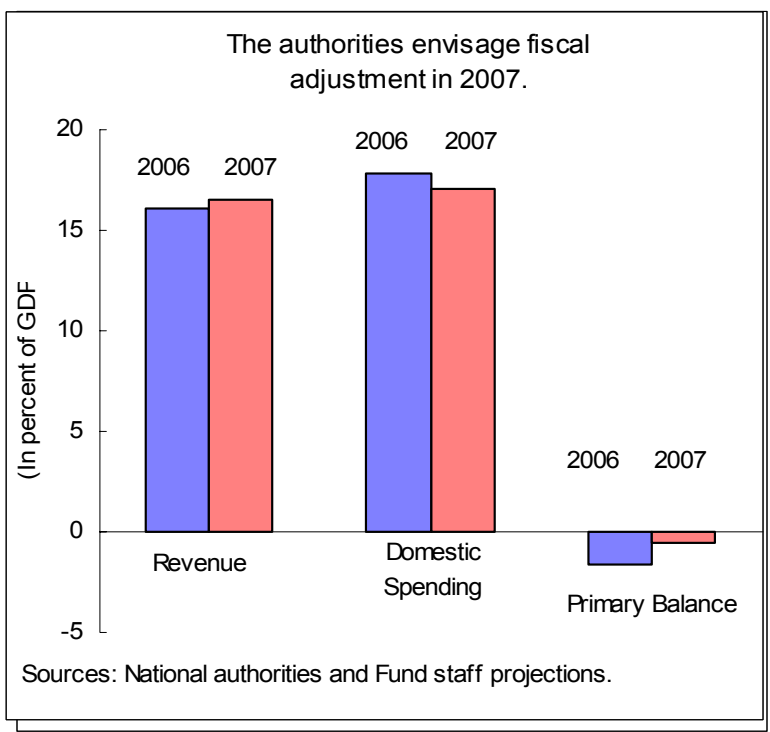
and arrears and strengthen revenue administration through audits and computerization. The most critical benchmark is to curtail drastically expenditures made through exceptional procedures as this will be the main tool for ensuring fiscal discipline in the context of growing spending pressures. Ongoing Fund technical assistance is supporting expenditure management and revenue administration and forthcoming recommendations may be incorporated into the SMP during the first review.

\section{Banking Sector}

\section{Recent budgetary injections and discount operations have reduced liquidity} pressures, but the largest state-owned banks remain severely undercapitalized. The government partially recapitalized several public banks in 2004 and early 2006 by taking over nonperforming debt (including about half of SOTOCO's debt and some private debt of about 4 percent of GDP) in exchange for government obligations, with annual amortization of just over $1 / 2$ percent of GDP paid by the budget. Liquidity pressures on a large state-owned bank subsided in September 2006 after the government injected CFAF 2 billion to cover an overdraft and the bank discounted a CFAF 12 billion claim on the government to a foreign

authorities intend to seek understandings on mechanisms for arrears clearance. With regard to bilateral creditors, financing assurances will need to be requested from Paris Club creditors ahead of a PRGF request. With regard to multilateral creditors, World Bank staff have indicated that a formal strategy toward arrears clearance would need to be defined in a strategy note following the completion of an updated I-PRSP. The fiscal program under the SMP provides a small contingency for debt service aimed at regularizing relations with creditors.

${ }^{5}$ The gap could be closed through new budget support from donors, debt service relief, and central bank financing based on a possible first tranche under a PRGF arrangement. 
bank. ${ }^{6}$ However, profitability remains low and bank management weak. The largest stateowned banks still have combined negative equity of about $3 \frac{1}{2}$ percent of GDP, and a private bank also appears severely undercapitalized.

\section{The mission agreed with the authorities on the principles of contingency}

planning for potential liquidity pressures. Representatives from the national branch of the BCEAO stressed that they have been monitoring banks' liquidity and financial position and that existing mechanisms for providing liquidity support have been sufficient. The government agreed with the mission on the general principles of contingency planning, including intensified monitoring of the two largest banks by the Ministry of Finance (as a structural benchmark under the SMP) and the principle that additional budget support would be contingent on banks implementing the recommendations and directives of the regional Banking Commission (Box 1).

20. The authorities acknowledged the urgent need to restructure ailing banks. The secretariat of the regional Banking Commission has carried out on-site missions and provided provisional recommendations for improving the banks' operations and financial position (including on strengthening management, provisioning, NPL recovery, risk analysis, and credit allocation policies). The mission urged the authorities to ensure that these recommendations, once finalized, ${ }^{7}$ are implemented without delay. During the first SMP review, the mission will discuss with the authorities which priority recommendations could be included as explicit commitments to be implemented during the SMP. More generally, the staff noted that the existing regulatory structure, with supervision dispersed between national and regional institutions, has failed to foster timely follow-up on supervisory recommendations. An upcoming regional FSAP will take up some of these questions.

\section{The authorities have committed to prepare a time-bound restructuring plan} aimed at the eventual privatization of state-owned banks. The preparation of this plan is a structural benchmark under the SMP that will require extensive coordination with the central bank and the regional banking supervisor, as well as technical assistance from the Fund and World Bank. Given the severe undercapitalization of Togo's large public banks, a credible plan will have significant budget implications. The staff estimates that covering the remaining bad debts of state-owned enterprises to the large public banks would cost about $2 \frac{1}{2}$ percent of GDP (which could be stretched over several years), but additional budgetary injections may be required to recapitalize them.

\footnotetext{
${ }^{6}$ The claim on the government is payable over seven years and secured by fiscal revenues withheld at the BCEAO. It was issued to the bank in early 2006 in exchange for SOTOCO's bad debt.

${ }^{7}$ The 2006 on-site inspection report by the secretariat staff is currently being discussed with the banks. The recommendations are not yet finalized and the banks' corrective measures have yet to be fully evaluated. Once the consultation process is concluded, the Board of the Banking Commission would determine a set of corrective actions..
} 


\section{Public Enterprise Reform}

22. A sustained increase in economic growth is unlikely without comprehensive reforms of state-owned enterprises. The authorities and staff agreed that repayment of SOTOCO's arrears to cotton farmers was a necessary condition for reviving the sector. However, several observers were skeptical about the cotton sector's near-term prospects, as margins remain low and farmers have largely shifted to other crops. ${ }^{8}$ The completion of financial and strategic audits of SOTOCO, a structural benchmark under the SMP, is seen as a first step toward preparing a more comprehensive restructuring strategy. During the SMP, Fund staff and the authorities will review the results of the audits to determine near-term steps to strengthen governance and performance. Implementation of a broader strategy might be delayed until key development partners, including the World Bank, can provide technical and financial assistance. The authorities also intend to launch an audit of the phosphate sector, as a structural benchmark under the SMP, although broader reform prospects are uncertain as long as the government remains in litigation with the existing foreign investor. Once the legal issues are resolved, the authorities intend to find a strong strategic investor to manage the company. The mission urged the authorities to review the financial situation of the energy sector, where quasi-fiscal losses are mounting and electricity is increasingly rationed, with several hours of power cuts each day.

\section{E. Medium-Term Poverty Reduction and Growth Strategy}

\section{The government is preparing an updated Interim Poverty Reduction and} Growth Strategy Paper (I-PRSP) for 2007-09. The authorities have requested technical assistance to evaluate the results of recent poverty surveys and prepare a medium-term macroeconomic framework. They are also consulting with key donors on potential external financing. The I-PRSP will be aimed at addressing Togo's poor economic growth performance and making progress toward the MDGs. This will require steps to shore up competitiveness, including through improved governance, a better investment climate, and comprehensive reforms of state-owned enterprises and banks. ${ }^{9}$ Strengthened macroeconomic policies will be critical to secure comprehensive debt relief and donor assistance in support of critical public investments and social expenditures. The upcoming Article IV mission, planned at the same time as the first review of the SMP, will update the medium-term macroeconomic framework based on the updated I-PRSP.

\section{The authorities hope to start a PRGF arrangement to anchor their economic} policies and pave the way for HIPC debt relief, but Togo's large external arrears are a significant obstacle. Staff noted that Board approval of a PRGF arrangement will require: (i) fully satisfactory performance under the SMP through June 2007; (ii) financing

\footnotetext{
${ }^{8}$ The number of cotton farmers is estimated to have fallen to 140,000 in 2006 , compared to 250,000 in previous years.

${ }^{9}$ For a review of external competitiveness and public enterprise performance, see the recent Ex Post Assessment of Longer Term Program Engagement and the latest Article IV staff report.
} 
assurances from donors; and (iii) understandings on external arrears clearance. Substantial interagency coordination will be needed to prepare for renewed financial support from major donors and creditors in the second half of 2007. The EU is preparing several large grants that could be used in part to help clear Togo's arrears to the European Investment Bank. The AfDB is considering mechanisms for clearing Togo's arrears through new country allocations. World Bank staff is initiating an interim country strategy note, but stressed that Togo's \$100 million in arrears to the Bank far exceed Togo's current IDA allocation, implying the need for a special allocation or donor support to help clear arrears.

\section{F. Program Monitoring and Risks}

25. The SMP covers the period October 1, 2006-June 30, 2007. The program details are in the government's LOI and MEFP (Attachment I). Definitions and data provision requirements are specified in the Technical Memorandum of Understanding (Attachment II). Quarterly quantitative targets (Attachment I, Table 1) include the primary fiscal balance, fiscal revenues, net domestic financing to government, and domestic and external arrears. Structural benchmarks (Attachment I, Table 2) include measures in the area of budget reform, revenue administration, expenditure management, banking sector reform, and public enterprise reform. A first review of the SMP will be conducted based on end-December 2006 quantitative performance and structural reform objectives through February 2007.

26. The government has set up a program monitoring unit to coordinate economic policies and reforms under the SMP. The authorities underlined their commitment to reestablishing credibility by fully meeting the quantitative and structural objectives under the SMP. This will require a mechanism for policymakers to be informed in real time about budget execution relative to monthly sub-targets. Staff underlined the importance of close coordination between government, the national branch of the BCEAO, and the regional Banking Commission on banking sector issues. The new program monitoring unit, led by a permanent secretary, is expected to play a key role in these areas and understandings were reached on the regular compilation and provision of fiscal, monetary, and banking data.

27. The proposed SMP will cover a politically volatile period, and the economy is vulnerable to external and financial sector shocks. The planned elections for mid-2007 would be the first free parliamentary contest since independence. Political competition in the months leading up to the elections could give rise to substantial budgetary pressures and waning reform momentum. If the elections are either delayed or not conducted in a free and fair manner, donor support is unlikely to rise to the projected levels. The economy is also vulnerable to exogenous shocks from weather, commodity prices, and conditions in neighboring countries. Moreover, a banking crisis cannot be ruled out, which would severely impact public finances and economic growth, and could spill over into the WAEMU region.

\section{Staff Appraisal}




\section{Togo is emerging from a long period of international isolation and economic} stagnation. The recent multiparty accord and the prospect of free parliamentary elections in 2007 have set in motion an important political reform process. The authorities have stressed their commitment to combine this process with improved governance, economic reforms, and reengagement with the donor community. Implementation of prior actions for the SMP was a first positive step in this direction.

29. A sustained economic recovery and poverty reduction would require policy adjustments, economic reforms, and renewed external assistance. Togo's traditional sectors such as cotton and phosphate can only be revitalized with significant reform and support from key development partners. By improving the business environment and governance, Togo could also expand its role as a regional trade hub. Addressing the country's many social problems would require improved expenditure management and a resumption of financial and technical assistance from donors.

30. The near-term priority is to preserve macroeconomic stability. The upcoming election campaign, losses among state-owned enterprises, and fragility of several large banks could spill over into the budget. The authorities will need to rein in discretionary spending during the SMP to prevent domestic arrears accumulation and ensure that sufficient resources are available for contingencies.

\section{Adopting and implementing a realistic 2007 budget will be important for} reestablishing policy credibility. The authorities have set the ambitious but realistic objective of reducing the primary deficit by about $1 \frac{1}{4}$ percentage points of GDP in 2007, consistent with macroeconomic stability and a tight financing constraint. The envisaged fiscal adjustment is based on a realistic revenue effort combined with tighter controls on discretionary spending.

\section{The near-term structural reform agenda aims to improve governance and} strengthen institutional capacity. Improved fiscal governance, in particular, will help ensure that the 2007 budget is implemented without incurring new domestic arrears. The highest priority is to improve expenditure management, including by curtailing exceptional spending procedures. Strengthening revenue administration through audits and computerization and introducing a monitoring system for budget execution will also be critical. Technical assistance will be necessary to support capacity building in these areas.

33. Several ailing banks are in urgent need of restructuring. Although partial recapitalizations of the two largest state-owned banks have alleviated liquidity pressures, the banks remain severely undercapitalized and unprofitable. Recent steps to intensify monitoring and develop contingency plans are welcome, and need to be complemented with the implementation of the regional supervisor's recommendations to improve the banks' financial position and prevent recurring liquidity problems. A comprehensive restructuring strategy should be prepared during the SMP period in coordination between the government, the BCEAO, the regional supervisor, the World Bank, and the Fund. 
34. Formulating a medium-term economic agenda is an important next step. This process should begin with financial and strategic audits of the cotton and phosphate sectors and a review of the energy sector. The authorities should also identify priority programs for public investment and social spending as they prepare an updated I-PRSP. The implementation of comprehensive reforms in these sectors will require reengagement with the World Bank and other development partners.

35. The authorities' economic program is subject to substantial risks. The SMP covers a politically charged period, with possibly significant budget pressures. A disruption of the political reform process would likely prevent the resumption of donor assistance. The weak financial positions of state-owned companies and banks pose additional fiscal risks. Togo is also exposed to exogenous shocks such as commodity price swings and changes in political and economic conditions in neighboring countries.

36. Notwithstanding these risks, the program could help preserve macroeconomic stability and unlock urgently needed external assistance. At a time when key development partners are exploring options for reengaging with Togo, the SMP provides an opportunity for the authorities to establish a track record of improved governance and policy implementation. Fully satisfactory performance under the SMP could pave the way for a PRGF arrangement and eventual HIPC debt relief, though Togo would first need to reach understandings with creditors and donors on arrears clearance and identify adequate program financing. 
Table 1. Togo: Selected Economic and Financial Indicators, 2003-07

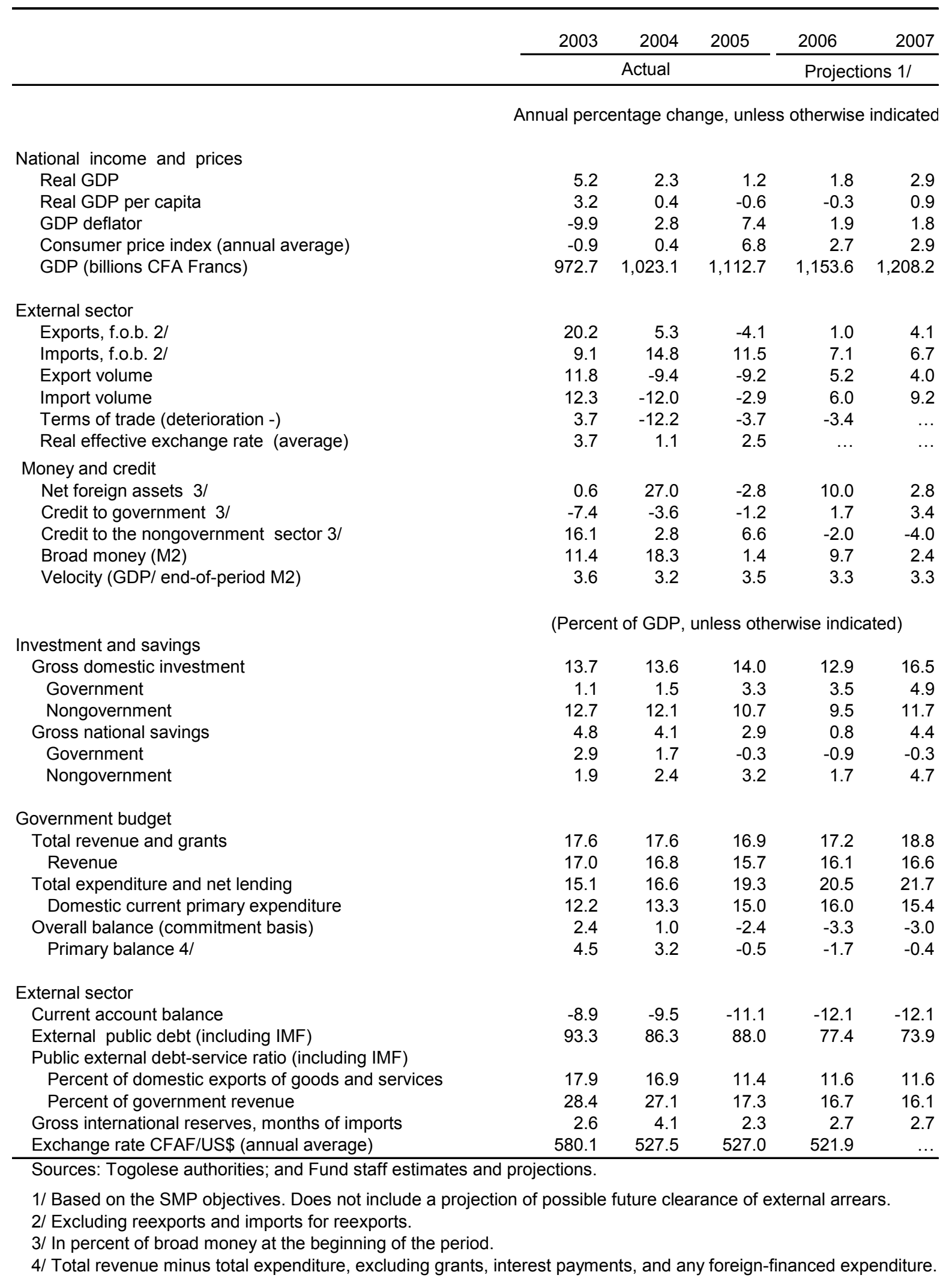


Table 2. Togo: Balance of Payments, 2004-10

\begin{tabular}{|c|c|c|c|c|c|c|c|}
\hline & 2004 & 2005 & 2006 & 2007 & 2008 & 2009 & 2010 \\
\hline & \multicolumn{2}{|c|}{ Actual } & \multicolumn{5}{|c|}{ Projections 1/ } \\
\hline & \multicolumn{7}{|c|}{ (Billions of CFA francs) } \\
\hline Current account balance & -97.2 & -123.0 & -139.7 & -146.7 & -142.3 & -137.2 & -133.8 \\
\hline Trade balance & -133.2 & -193.0 & -223.2 & -245.9 & -251.2 & -259.1 & -270.6 \\
\hline Total exports & 317.5 & 309.0 & 322.7 & 343.6 & 366.1 & 386.4 & 408.4 \\
\hline Domestic exports & 275.8 & 264.5 & 267.0 & 278.0 & 299.2 & 316.7 & 336.8 \\
\hline Of which: cotton & 42.1 & 33.9 & 20.4 & 12.4 & 20.2 & 22.0 & 24.0 \\
\hline phosphates & 25.4 & 18.4 & 20.3 & 24.6 & 26.0 & 27.6 & 29.3 \\
\hline cement and clinker & 61.7 & 52.2 & 55.1 & 61.2 & 64.3 & 67.5 & 70.8 \\
\hline Reexports & 41.7 & 44.5 & 55.7 & 65.7 & 66.9 & 69.7 & 71.5 \\
\hline Imports, f.o.b. & -450.7 & -502.0 & -545.9 & -589.5 & -617.3 & -645.4 & -678.9 \\
\hline Domestic imports & -417.4 & -465.4 & -498.5 & -531.7 & -558.5 & -584.1 & -616.0 \\
\hline Of which: import of petroleum products & -132.6 & -187.6 & -215.7 & -234.5 & -234.6 & -232.2 & -230.8 \\
\hline Imports for reexports & -33.3 & -36.6 & -47.5 & -57.8 & -58.8 & -61.3 & -63.0 \\
\hline Services (net) & -49.1 & -40.4 & -38.2 & -32.5 & -25.9 & -18.2 & -9.9 \\
\hline Credit & 74.8 & 98.8 & 113.4 & 127.0 & 139.7 & 153.7 & 169.0 \\
\hline Debit & -123.9 & -139.2 & -151.6 & -159.5 & -165.7 & -171.8 & -178.9 \\
\hline Income (net) & -17.7 & -9.4 & -13.0 & -13.7 & -14.3 & -15.0 & -15.8 \\
\hline Of which: interest on external debt & -13.0 & -10.9 & -9.9 & -9.2 & -8.7 & -8.2 & -8.2 \\
\hline Current transfers (net) & 102.8 & 119.8 & 134.7 & 145.3 & 149.2 & 155.1 & 162.4 \\
\hline Private & 93.2 & 109.1 & 124.6 & 132.5 & 133.7 & 135.0 & 136.3 \\
\hline Public & 9.6 & 10.7 & 10.1 & 12.9 & 15.5 & 20.1 & 26.1 \\
\hline Capital and financial account & 84.6 & 90.9 & 139.7 & 108.9 & 103.9 & 96.7 & 96.7 \\
\hline Capital account (capital transfers) & 7.9 & 13.1 & 12.0 & 26.6 & 35.0 & 39.4 & 44.3 \\
\hline Financial acoount & 76.7 & 77.8 & 127.7 & 82.3 & 68.9 & 57.3 & 52.4 \\
\hline Direct investment & 38.0 & 24.2 & 39.8 & 42.7 & 48.9 & 56.6 & 66.4 \\
\hline Other investment & 38.7 & 53.6 & 87.9 & 39.6 & 20.0 & 0.7 & -14.0 \\
\hline General government & -28.6 & -9.5 & -6.1 & -3.6 & -2.1 & 4.2 & 10.7 \\
\hline Disbursements & 4.9 & 9.9 & 15.0 & 19.4 & 24.8 & 31.8 & 38.3 \\
\hline Amortization & -33.5 & -19.4 & -21.1 & -23.0 & -26.9 & -27.6 & -27.6 \\
\hline Commercial banks' net foreign assets & -25.3 & -13.5 & -3.0 & 0.0 & 0.0 & 0.0 & 0.0 \\
\hline Other capital & 92.7 & 76.6 & 97.1 & 43.2 & 22.2 & -3.5 & -24.7 \\
\hline Of which: Trade credit & 34.7 & 47.1 & 56.1 & 22.0 & 21.8 & 13.9 & 14.1 \\
\hline Errors and omissions & 14.2 & -13.3 & 0.0 & 0.0 & 0.0 & 0.0 & 0.0 \\
\hline Overall balance & 1.7 & -45.5 & 0.0 & -37.8 & -38.4 & -40.5 & -37.1 \\
\hline Financing & -1.7 & 45.5 & 0.0 & 37.8 & 38.4 & 40.5 & 37.1 \\
\hline Change in net foreign assets (- increase) & -47.1 & 22.3 & -29.0 & -10.0 & -12.3 & -7.3 & -8.7 \\
\hline Of which: net use of Fund resources & -8.5 & -6.0 & -6.0 & -3.4 & -0.8 & 0.0 & 0.0 \\
\hline Change in arrears (reduction -) & 45.4 & 29.0 & 29.0 & 32.2 & 0.0 & 0.0 & 0.0 \\
\hline Unidentified financing & 0.0 & -5.8 & 0.0 & 15.6 & 50.7 & 47.7 & 45.7 \\
\hline Memorandum items: & & (Perce & f GDP, ur & ss other & se indica & & \\
\hline Current account balance, incl. transfers & -9.5 & -11.1 & -12.1 & -12.1 & -11.0 & -9.9 & -9.0 \\
\hline Trade balance & -13.0 & -17.3 & -19.3 & -20.3 & -19.4 & -18.7 & -18.1 \\
\hline Exports of goods & 31.0 & 27.8 & 28.0 & 28.4 & 28.3 & 27.9 & 27.4 \\
\hline Imports of goods & -44.1 & -45.1 & -47.3 & -48.8 & -47.8 & -46.6 & -45.5 \\
\hline
\end{tabular}

Sources: Togolese authorities; and Fund staff estimates and projections.

1/ Based on an adjustment scenario with fiscal consolidation, enhanced donor support, and structural reforms to improve competitiveness. Does not include projections for possible arrears clearance, IMF financing, or future debt relief under the HIPIC initiative. The medium-term assumptions are broadly based on the lastest Article IV consultation (SM 06/133). A revised medium-term framework will be prepared for the next Article IV consultation, based on an updated I-PRSP and a scenario for debt relief. 
Table 3. Togo: Financial Operations of the Central Government, 2005-07 (Cont.)

\begin{tabular}{|c|c|c|c|c|c|c|}
\hline & \multirow{2}{*}{$\begin{array}{c}2005 \\
\text { Actual }\end{array}$} & \multicolumn{3}{|c|}{2006} & \multicolumn{2}{|c|}{2007} \\
\hline & & Budget & $\begin{array}{c}\text { Jan-Jun. } \\
\text { Act. }\end{array}$ & $\begin{array}{c}\text { Jan-Dec. } \\
\text { Prog. 1/ }\end{array}$ & $\begin{array}{l}\text { Jan-Jun. } \\
\text { Prog. 1/ }\end{array}$ & $\begin{array}{c}\text { Jan-Dec. } \\
\text { Proj. 1/ }\end{array}$ \\
\hline & \multicolumn{6}{|c|}{ (Billions of CFA francs) } \\
\hline Revenue and grants & 188.0 & 203.3 & 94.2 & 197.9 & 106.8 & 226.7 \\
\hline Total revenue & 174.9 & 184.3 & 88.3 & 185.9 & 95.0 & 200.1 \\
\hline Tax revenue & 162.1 & 164.2 & 85.8 & 175.9 & 90.0 & 185.1 \\
\hline Tax administration (DGI) & 81.0 & 85.1 & 41.2 & 84.0 & 43.0 & 87.6 \\
\hline Customs administration (DGD) & 81.0 & 79.1 & 44.6 & 91.9 & 47.0 & 97.5 \\
\hline Nontax revenue & 12.8 & 20.1 & 2.6 & 10.0 & 5.0 & 15.0 \\
\hline Grants & 13.1 & 19.0 & 5.9 & 12.0 & 11.8 & 26.6 \\
\hline Expenditures and net lending & 215.0 & 243.7 & 109.6 & 236.4 & 129.2 & 262.8 \\
\hline Current expenditures & 178.4 & 166.8 & 92.2 & 196.6 & 101.2 & 203.9 \\
\hline Primary current expenditures & 166.8 & 152.8 & 87.1 & 184.5 & 93.6 & 185.6 \\
\hline Wages and salaries $2 /$ & 49.2 & 56.8 & 25.1 & 58.0 & 31.0 & 63.9 \\
\hline Goods and services & 46.9 & 50.3 & 19.5 & 43.7 & 23.7 & 49.8 \\
\hline Subsidies and transfers & 26.6 & 40.6 & 21.6 & 49.0 & 28.3 & 51.7 \\
\hline Of which: transfer to clear SOTOCO arrears & $\ldots$ & 0.0 & 0.0 & 10.5 & 6.0 & 6.0 \\
\hline Autonomous and local entities & 8.2 & 5.1 & 0.5 & 5.2 & 2.2 & 5.2 \\
\hline Other 3/ & 35.9 & 0.0 & 20.4 & 28.6 & 8.5 & 15.0 \\
\hline Foreign financed current expenditure 4/ & 0.0 & 0.0 & 0.0 & 1.5 & 2.0 & 7.0 \\
\hline Interest & 11.6 & 14.0 & 5.1 & 10.6 & 5.6 & 11.2 \\
\hline Domestic debt & 0.7 & 3.9 & 0.3 & 0.7 & 1.0 & 2.0 \\
\hline External debt & 10.9 & 10.0 & 4.9 & 9.9 & 4.6 & 9.2 \\
\hline Public investment & 36.6 & 76.9 & 17.4 & 39.8 & 28.1 & 58.9 \\
\hline Domestically financed & 13.6 & 38.7 & 5.7 & 20.7 & 8.5 & 19.7 \\
\hline Of which: bond financed program & $\ldots$ & 30.0 & 0.0 & 13.0 & 4.0 & 9.6 \\
\hline Externally financed & 23.0 & 38.2 & 11.6 & 19.1 & 19.6 & 39.2 \\
\hline Domestic primary balance 5/ & -5.5 & -7.2 & -4.5 & -19.3 & -7.0 & -5.2 \\
\hline Overall balance incl. grants, commitment basis & -27.0 & -40.4 & -15.4 & -38.5 & -22.4 & -36.1 \\
\hline Change in arrears and treasury float & 31.1 & 0.9 & 0.3 & 9.4 & 4.6 & 9.2 \\
\hline Change in unpaid treasury payments orders & 19.7 & -6.6 & 0.1 & 4.8 & 0.0 & 0.0 \\
\hline Other domestic arrears & 1.0 & 0.0 & -4.6 & -4.8 & 0.0 & 0.0 \\
\hline Interest on external debt & 10.4 & 7.5 & 4.7 & 9.4 & 4.6 & 9.2 \\
\hline Overall balance, cash basis & 4.1 & -39.5 & -15.1 & -29.1 & -17.8 & -26.8 \\
\hline Financing & 1.8 & 26.0 & 16.6 & 34.7 & 17.8 & 11.2 \\
\hline Domestic financing (net) & -7.3 & 6.8 & 11.2 & 27.9 & 9.7 & -4.9 \\
\hline Banking system & -3.7 & -8.8 & -24.9 & 1.5 & 13.2 & 8.8 \\
\hline Of which: IMF & -6.0 & -6.0 & -1.8 & -3.6 & -1.6 & -3.3 \\
\hline central bank & 6.1 & -2.2 & -27.1 & 1.3 & 13.8 & 10.8 \\
\hline commercial banks & -3.8 & -0.6 & 4.0 & 3.8 & 1.0 & 1.3 \\
\hline Of which: Bond & $\ldots$ & $\ldots$ & 3.5 & 3.5 & 0.0 & -0.7 \\
\hline Nonbank financing & 4.1 & 22.5 & 39.7 & 33.3 & 0.0 & -6.8 \\
\hline Bond (foreign banks and Togolese nonbanks) & 0.0 & $\ldots$ & 32.5 & 32.5 & 0.0 & -6.8 \\
\hline Amortization of NPLs guaranteed by govt. & -7.7 & -6.9 & -3.6 & -6.9 & -3.5 & -6.9 \\
\hline External financing (net) & 9.1 & 19.2 & 5.4 & 6.8 & 8.1 & 16.1 \\
\hline Drawings & 9.9 & 19.2 & 5.7 & 8.6 & 9.8 & 19.6 \\
\hline Amortization due & -19.4 & -22.8 & -9.3 & -21.1 & -11.1 & -23.0 \\
\hline Arrears on amortization & 18.6 & 22.8 & 9.1 & 20.7 & 11.1 & 23.0 \\
\hline Contingency for debt service & $\ldots$ & $\ldots$ & $\ldots$ & -1.4 & -1.7 & -3.5 \\
\hline Discrepancy/unidentified financing & -5.8 & 13.5 & -1.5 & -5.5 & 0.0 & 15.6 \\
\hline
\end{tabular}


Table 3. Togo: Financial Operations of the Central Government, 2005-07 (Concl.)

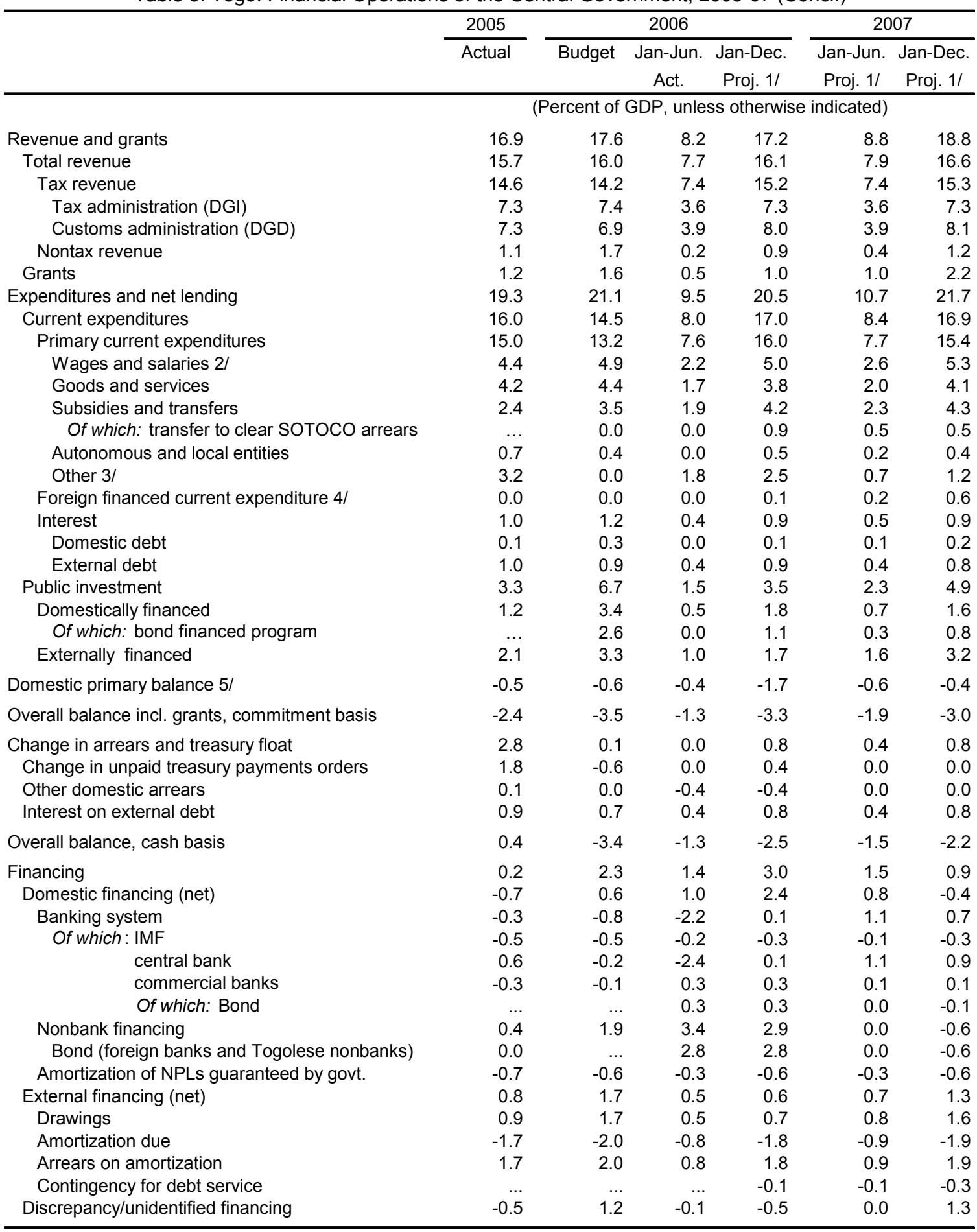

Sources: Togolese authorities; and Fund staff estimates and projections.

1/ Program for Jan.-Dec. 2006 and Jan.-Jun. 2007 based on SMP objectives. The projection for 2007 reflects draft budget submitted to parliament on Dec. 11, 2006. The projections do not include possible future external arrears clearance.

2/ Includes conversion of 12,000 teachers from contractuals into civil servants in 2006 and 2007.

3 / Includes (i) offbudget spending in 2005 and early 2006 based on customs and tax revenues not transferred to Treasury,

(ii) unclassified spending, and (iii) contingency for emergency spending, including possible bank restructuring in 2007. 4/ Including for elections and repayment of SOTOCO's arrears to cotton farmers.

5 / Excluding grants, interest, and externally financed spending. 
Table 4. Togo: Monetary Survey, 2003-07

\begin{tabular}{|c|c|c|c|c|c|c|c|}
\hline & 2003 & 2004 & 2005 & \multicolumn{3}{|c|}{2006} & 2007 \\
\hline & Dec. & Dec. & Dec. & $\begin{array}{l}\text { June } \\
\text { Est. }\end{array}$ & $\begin{array}{l}\text { Sept } \\
\text { Est. }\end{array}$ & $\begin{array}{c}\text { Dec. } \\
\text { Proj. 1/ }\end{array}$ & $\begin{array}{l}\text { Dec. } \\
\text { Proj. 1/ }\end{array}$ \\
\hline & \multicolumn{7}{|c|}{ (Billions of CFA francs) } \\
\hline Net foreign assets & 81.5 & 153.9 & 145.1 & 203.2 & 209.7 & 177.1 & 187.1 \\
\hline BCEAO & 67.2 & 114.2 & 91.9 & 153.2 & 155.2 & 120.9 & 130.9 \\
\hline Commercial banks & 14.3 & 39.7 & 53.2 & 50.0 & 54.6 & 56.2 & 56.2 \\
\hline Net domestic assets & 186.6 & 163.4 & 176.6 & 143.2 & 161.1 & 175.7 & 173.3 \\
\hline Credit to the government (net) & 25.5 & 15.9 & 12.0 & 10.4 & 12.9 & 17.6 & 29.7 \\
\hline BCEAO & 28.1 & 7.0 & 7.1 & -21.9 & -12.9 & 8.9 & 19.7 \\
\hline Commercial banks & -2.6 & 8.8 & 5.0 & 32.3 & 25.9 & 8.8 & 10.1 \\
\hline $\begin{array}{l}\text { Credit to the rest of the economy } \\
\text { Other items (net) }\end{array}$ & $\begin{array}{r}166.7 \\
-5.6\end{array}$ & $\begin{array}{l}174.1 \\
-26.6\end{array}$ & $\begin{array}{l}195.1 \\
-30.5\end{array}$ & $\begin{array}{l}165.4 \\
-32.6\end{array}$ & $\begin{array}{l}175.0 \\
-26.8\end{array}$ & $\begin{array}{l}188.6 \\
-30.5\end{array}$ & $\begin{array}{l}174.5 \\
-31.0\end{array}$ \\
\hline Money supply (M2) & 268.2 & 317.3 & 321.7 & 346.4 & 370.8 & 352.8 & 361.2 \\
\hline Currency in circulation & 48.6 & 73.4 & 63.2 & 70.1 & 82.1 & 73.2 & 66.2 \\
\hline \multirow[t]{2}{*}{ Bank deposits } & 219.6 & 243.9 & 258.5 & 276.3 & 288.8 & 279.6 & 295.0 \\
\hline & \multicolumn{7}{|c|}{ (Annual change, percent of beginning-of-the period broad money) } \\
\hline Net foreign assets & 0.6 & 27.0 & -2.8 & 18.1 & 20.1 & 10.0 & 2.8 \\
\hline BCEAO & 2.8 & 17.5 & -7.0 & 19.1 & 19.7 & 9.0 & 2.8 \\
\hline Commercial banks & -2.2 & 9.4 & 4.3 & -1.0 & 0.4 & 0.9 & 0.0 \\
\hline Net domestic assets & 10.8 & -8.7 & 4.2 & -10.4 & -4.8 & -0.3 & -0.7 \\
\hline Credit to the government (net) & -7.4 & -3.6 & -1.2 & -0.5 & 0.3 & 1.7 & 3.4 \\
\hline Credit to the rest of the economy & 16.1 & 2.8 & 6.6 & -9.2 & -6.2 & -2.0 & -4.0 \\
\hline Other items (net) & 2.1 & -7.8 & -1.2 & -0.7 & 1.2 & 0.0 & -0.1 \\
\hline Money supply (M2) & 11.4 & 18.3 & 1.4 & 7.7 & 15.3 & 9.7 & 2.4 \\
\hline Currency in circulation & -6.1 & 9.2 & -3.2 & 2.1 & 5.9 & 3.1 & -2.0 \\
\hline Bank deposits & 17.5 & 9.1 & 4.6 & 5.5 & 9.4 & 6.6 & 4.4 \\
\hline \multicolumn{8}{|l|}{ Memorandum items } \\
\hline Velocity (GDP/ end-of-period M2) & 3.6 & 3.2 & 3.5 & $\ldots$ & $\ldots$ & 3.3 & 3.3 \\
\hline
\end{tabular}

Sources: Central Bank of West African States (BCEAO) and Fund staff estimates and projections.

$1 /$ Based on the SMP objectives. 
Table 5. Togo: Official External Debt

\begin{tabular}{|c|c|c|c|c|}
\hline & \multicolumn{2}{|c|}{2004} & \multicolumn{2}{|c|}{2005} \\
\hline & Total & $\begin{array}{r}\text { Of which } \\
\text { arrears }\end{array}$ & Total & $\begin{array}{r}\text { Of which } \\
\text { arrears }\end{array}$ \\
\hline & \multicolumn{4}{|c|}{ (Millions of U.S. dollars) } \\
\hline Total & $1,804.1$ & 507.8 & $1,770.0$ & 518.0 \\
\hline Multilateral & $1,017.6$ & 106.1 & $\ldots$ & 127.7 \\
\hline of which: World Bank & 731.0 & 59.1 & $\ldots$ & 80.6 \\
\hline AfDB & 133.6 & 10.2 & $\ldots$ & 18.1 \\
\hline Other & 152.6 & 36.4 & $\ldots$ & 29.0 \\
\hline Bilateral & 786.5 & 401.8 & $\ldots$ & 390.2 \\
\hline of which: Paris Club & 629.0 & 369.5 & $\ldots$ & 349.9 \\
\hline \multirow[t]{2}{*}{ Non-Paris Club } & 157.5 & 32.2 & $\ldots$ & 40.4 \\
\hline & \multicolumn{4}{|c|}{ (Percent of GDP, unless otherwise indicated) } \\
\hline Total & 86.3 & 24.3 & 88.0 & 25.8 \\
\hline Multilateral & 48.7 & 5.1 & $\ldots$ & 6.4 \\
\hline of which: World Bank & 35.0 & 2.8 & $\ldots$ & 4.0 \\
\hline AfDB & 6.4 & 0.5 & $\ldots$ & 0.9 \\
\hline Other & 7.3 & 1.7 & $\ldots$ & 1.4 \\
\hline Bilateral & 37.6 & 19.2 & $\ldots$ & 19.4 \\
\hline of which: Paris Club & 30.1 & 17.7 & $\ldots$ & 17.4 \\
\hline Non-Paris Club & 7.5 & 1.5 & $\ldots$ & 2.0 \\
\hline \multicolumn{5}{|l|}{ Memorandum item } \\
\hline Nominal GDP & 1023.1 & & 111 & \\
\hline Exchange rate CFAF/USD (end-of-year) & 489.3 & & 55 & \\
\hline
\end{tabular}

Sources: Togolese authorities, and Fund staff estimates. 


\section{APPENDIX I-TOGO: RELATIONS WITH THE FUND}

(As of October 31, 2006)

I. Membership Status: Joined August 1, 1962; Article VIII

II. General Resources Account:

Quota

Fund holdings of currency

Reserve position in the Fund

III. SDR Department:

Net cumulative allocation

Holdings

IV. Outstanding Purchases and Loans:

Poverty Reduction and Growth Facility

(PRGF) arrangements
SDR million

73.40

73.07

0.33

SDR million

10.98

0.17

SDR million

5.43
Percent of quota

100.00

99.55

0.45

Percent of allocation

100.00

1.52

Percent of quota

7.40

V. Financial Arrangements:

\begin{tabular}{lcccc}
\multicolumn{1}{c}{ Type } & $\begin{array}{c}\text { Approval } \\
\text { Date }\end{array}$ & $\begin{array}{c}\text { Expiration } \\
\text { Date }\end{array}$ & $\begin{array}{c}\text { Amount Approved } \\
\text { (SDR million) }\end{array}$ & $\begin{array}{c}\text { Amount Drawn } \\
\text { (SDR million) }\end{array}$ \\
PRGF & $09 / 16 / 94$ & $06 / 29 / 98$ & 65.16 & 54.30 \\
PRGF & $05 / 31 / 89$ & $05 / 19 / 93$ & 46.08 & 38.40 \\
Structural & $03 / 16 / 88$ & $05 / 30 / 89$ & 26.88 & 7.68 \\
Adjustment & & & & \\
Facility (SAF) & & & &
\end{tabular}

VI. Projected Obligations to the Fund: Under the Repurchase Obligations Assumption ${ }^{1}$ (SDR million; based on existing use of resources and present holdings of SDRs)

\begin{tabular}{lrrrrr} 
& \multicolumn{5}{c}{ Forthcoming } \\
& 2006 & 2007 & 2008 & 2009 & 2010 \\
Principal & & 4.34 & 1.09 & 0.00 & 0.00 \\
Charges/interest & 0.12 & 0.45 & 0.44 & 0.44 & 0.44 \\
Total & 0.12 & 4.79 & 1.52 & 0.44 & 0.44
\end{tabular}

\footnotetext{
${ }^{1}$ Repurchase obligations: repurchase in the credit tranches, including the Compensatory Financing Facility, are to be completed in $3 \frac{1}{4}-5$ years. Repurchases under the Extended Fund Facility are due in $4 \frac{1}{2}-10$ years.
} 


\section{Exchange Arrangement}

Togo is a member of the West African Economic and Monetary Union (WAEMU). The exchange system common to all WAEMU countries is free of restrictions on the making of payments and transfers for current international transactions. The union's common currency, the CFA franc, is pegged to the euro at the rate of CFAF $655.957=€ 1$, consistent with the official conversion rate of the French franc to the euro and the previous fixed rate of the CFA franc to the French franc of CFAF $100=$ F 1 . On April 28, 2006, the rate of the CFA franc in terms of the SDR was CFAF 769.68 = SDR 1.

\section{Safeguards Assessments}

The Central Bank of the West African States (BCEAO) is the common central bank of the countries of the WAEMU. A new safeguards assessment of the BCEAO was completed on November 4, 2005. The assessment found that progress has been made in strengthening the BCEAO's safeguards framework since 2002, when the last safeguards assessment took place.

The BCEAO now publishes a full set of audited financial statements, and improvements have been made to move financial reporting closer to International Financial Reporting Standards (IFRS). Furthermore, an internal audit charter has been put in place, mechanisms have been established to improve risk management and risk prevention, and follow-up on internal and external audit recommendations has been strengthened.

The new assessment identified a number of areas where further steps would help solidify the progress made. The main recommendations relate to improvements in the external audit process (including the adoption of a formal rotation policy), further enhancement of the transparency of the financial statements by fully adopting IFRS, and further strengthening of the effectiveness of the internal audit function.

\section{Article IV Consultation}

Togo is on the standard 12-month Article IV consultation cycle. The 2005 Article IV consultation was completed by the Executive Board on May 8, 2006. 


\section{Technical Assistance}

\section{Department Type of Assistance Time of Delivery Purpose}

$\begin{array}{llll}\text { MFD } & \text { Staff } & \text { March } 2006 & \text { Financial Sector } \\ \text { FAD } & \text { Staff } & \text { January } 2006 & \text { Revenue Administration } \\ \text { TGS } & \text { Staff } & \text { June } 2001 & \text { Computerization of treasury } \\ \text { FAD } & \text { Staff } & \text { July } 2000 & \text { Public expenditure management } \\ \text { FAD } & \text { Resident advisor } & 1997 & \text { Tax administration } \\ \text { FAD } & \text { Resident advisor } & \text { July } 1996 & \text { Customs administration } \\ \text { FAD } & \text { Staff } & \text { February } 1995 & \text { Tax reform } \\ \text { FAD } & \text { Staff } & \text { September } 1994 & \text { Public expenditure management } \\ \text { FAD } & \text { Staff } & \text { February } 1992 & \text { Tax reform } \\ \text { FAD } & \text { Staff } & \text { November } 1991 & \text { Budgetary reform }\end{array}$

\section{Resident Representative}

In September 2005, Mr. Koffi Yao became resident representative for Benin and Togo. 


\section{APPENDIX II. TOGO: RELATIONS WITH THE WORLD BANK}

(Updated December 7, 2006)

1. Over the last decade, Togo has been trapped in a vicious cycle of sociopolitical impasse, economic decline, rising poverty, and donor disengagement. Togo has been in nonaccrual status with the International Development Association (IDA) since May 2002, with arrears of US\$92.2 million as of August 2006. During the current non-accrual period, the Bank has continued to provide analytical and advisory assistance (AAA) on key aspects of socioeconomic development. Together with other partners, the Bank also supported the government's efforts to prepare its I-PRSP and development strategies in such sectors as health, education, agriculture and rural development, and HIV/AIDS.

2. Since early 2004 prospects for reengagement have improved owing to increasing political dialogue within the country and between the international community and the authorities. Within the framework of the Cotonou Partnership agreement between the government and the EU, the authorities committed to specific actions, including fair and transparent legislative elections, to pave the way for a resumption of financial assistance. These elections are now planned for mid2007. The government has also launched a process of national dialogue with the opposition parties in line with its political engagements with the EU. The political dialogue was positively concluded on August 20, 2006, with the signing by all parties involved of an "Accord Politique Global". This agreement should rapidly allow for the normalization of cooperation between Togo and the European Union.

3. The World Bank Executive Board discussed on December 14, 2004, a Country Reengagement Note (CRN) for Togo. It provides a joint strategy for Bank and UNDP reengagement and a framework for strengthening donor assistance that would lead to a clearance of Togo's arrears to IDA and other major creditors and a full resumption of Bank operations in the country.

4. In July 2005, the Bank approved a US\$2.8 million grant under the Low Income Country Under Stress (LICUS) Initiative for a community-driven Emergency Program for Poverty Reduction (EPPR), which aims at halting extreme poverty and the deterioration of social indicators. The first phase of this program was launched in October 2005; an evaluation including independent consultants was conducted in October 2006. The internal evaluation was positive, as a result of which the last phase of the EPPR is in negotiation pending the final report of the independent team. On the analytical side, the Bank is working closely with the IMF on a Financial Sector Assessment, an Urban Sector Stocktaking Study, and an Agricultural Development assessment, and has carried out a Public Expenditure and Financial Management Assessment. In addition, the Bank is supporting the government as it strengthens its poverty diagnosis, information systems, and statistical capacities and is helping to improve its institutional capacities. A Core Welfare Indicator Questionnaire survey was carried out in 2006 to provide for recent and more reliable statistics.

Contact person: Mr. Eric Nelson, phone (202) 4736699. 
December 21, 2006

Mr. Rodrigo de Rato

Managing Director

International Monetary Fund

Washington, D.C. 20431

Dear Mr. de Rato,

Following a decade of economic stagnation and political instability, Togo has embarked on momentous political and economic changes. The political agreement signed by all major political parties in August 2006 has strengthened the framework for holding free and fair elections in 2007. A national unity government was formed in September 2006. Over the last year, we have initiated important economic reforms, in particular in public finance, the cotton sector, and banking.

The government requests that our economic policies be supported by a nine-month StaffMonitored Program (SMP) for the period October 1, 2006 through June 30, 2007. Our policies are specified in the attached Memorandum of Economic and Financial Policies and Technical Memorandum of Understanding. The SMP's main purpose will be to support our efforts to maintain macroeconomic stability and improve governance, especially in the fiscal area, but also in banking and public enterprises. During the SMP period, we will intensify our efforts to set the conditions necessary for restarting external assistance programs with other international partners, including the World Bank, the AfDB, and the European Union.

If the SMP targets through end-June 2007 are met and we reach understandings on program financing and external arrears clearance, we would like to request the approval of a PRGF arrangement in the second half of 2007. Such an arrangement would help maintain macroeconomic stability and support a medium-term reform strategy aimed at raising economic growth and reducing poverty. In preparation, we are updating our Interim Poverty Reduction and Growth Strategy in a broad consultative effort. A PRGF arrangement would also open the way for debt relief under the HIPC initiative and MDRI.

Throughout the SMP, the government will consult with the Managing Director and Fund staff, at its own initiative or at your request, on Togo's economic and financial policies. We will provide Fund staff with the information it requests for monitoring program implementation.

Sincerely yours, $/ \mathrm{s} /$

Minister of Finance, Budget and Privatization 


\section{Togo: Memorandum of Economic and Financial Policies}

\section{BACKGROUND}

1. Following a decade of political and social instability, economic stagnation, and suspension of donor assistance, a national consensus has been reached to reform Togo's political and institutional framework and normalize relations with the international community. In August 2006, all political parties signed a historic agreement defining a roadmap for holding free and fair legislative elections in 2007. A government of national unity was formed in September, including the ruling party, opposition parties, and members of civil society. An independent national electoral commission was formed in October 2006.

2. In parallel with the political reform process, Togo will have to address its protracted economic problems. After a favorable economic environment and rising living standards in the 1970s and 1980s, real per capita income declined significantly between 1990 and 2005. Togo's main donors and lenders suspended assistance in the mid-1990s as political conflict contributed to a weakening of economic policies and reform. A relaxation of fiscal discipline, combined with a sharp drop in foreign aid, led to a rapid accumulation of arrears. Adverse terms of trade, poor internal pricing policies, and weak management caused mounting losses of public enterprises, in particular in the cotton and phosphate sectors, which accumulated large arrears to farmers, suppliers, and banks. As a result, Togo's large state-owned banks are burdened by high nonperforming loans, and some are highly undercapitalized.

3. The economic decline has reduced living standards for large segments of the population. Poverty has deepened in rural areas, and pockets of extreme poverty exist in urban areas, including the capital. The weakness of public finances has eroded resources for vital public services such as health and education, where there is a significant backlog in maintaining hospitals and schools, while hiring and wage freezes have led to serious bottlenecks in staffing schools and health facilities.

4. In this difficult economic environment, Togo's membership in the West African Economic and Monetary Union (WAEMU) has been an anchor of macroeconomic stability. Inflation has remained moderate, supported by the monetary policy of the regional central bank (BCEAO) and anchored by WAEMU fiscal policy targets. External imbalances have widened in recent years due to the problems in key export sectors, higher oil prices, and an appreciation of the real effective exchange rate. International reserves have, however, remained stable, as inflows private transfers and capital have largely offset the increase in the trade deficit.

5. Implementation of fiscal policy has been constrained by severe weaknesses in expenditure management and budgetary transparency. There were frequent expenditure overruns and large expenditures through off-budget operations and exceptional procedures, resulting in the accumulation of substantial domestic and external arrears. As a result, budget execution deviated frequently from budget provisions, and the budget process ceased to be an effective instrument of economic policy. 
6. Since 2005, we have taken important reform measures to restore sound economic policies. Several of these were coordinated with IMF staff as prior actions for the SMP. In particular:

- $\quad$ Reforms have been launched in the cotton sector. Domestic producer and input prices were adjusted to reflect international price levels. An audit of arrears to cotton farmers by the state-owned cotton company SOTOCO was completed in June 2006. The government paid a quarter of these arrears in July and adopted a repayment schedule for the remaining tranches in 2006 and 2007. A financial and strategic audit of SOTOCO was initiated to examine the reasons for past arrears and provide a basis for a sector reform strategy.

- Important measures have been taken to strengthen fiscal governance. The management of the customs and tax administration was replaced and all bank accounts of the tax and customs administration outside the control of the treasury were closed. All tax and customs revenues are now transferred, at least once a week, to the treasury's account at the central bank (BCEAO). The proceeds of the 2006 regional bond issue were also deposited at the BCEAO. The treasury now reviews once a month whether reported tax and customs revenues match inflows to the treasury account. A review of bank accounts of autonomous public agencies was completed.

- $\quad$ The government has made efforts to address the difficulties of state-owned banks. The state took over in early 2006 CFAF 23 billion of bad loans of SOTOCO, in recognition that the company had undertaken infrastructure work in rural areas and that its losses largely reflected the state's pricing policies that kept producer prices above (and input prices below) market prices. The government has intensified its monitoring of the liquidity situation of state-owned banks and considered the general principles of contingency plans.

\section{Objectives}

\section{Staff-Monitored Program}

7. The main purpose of our Staff-Monitored Program (SMP) is to safeguard economic stability and make progress on economic reform in a period of political reconciliation and reform. To this end, we will focus on improving governance and transparency in the fiscal area, the banking sector, and public enterprises. Strong performance under the SMP through June 2007 should provide the necessary track record for a PRGF arrangement, which could open the way for eventual debt relief under the HIPC initiative and MDRI.

\section{Economic outlook for the remainder of 2006 and for 2007}

8. Real GDP growth is projected to pick up moderately in 2006, driven by trade and transport services related to Togo's increasing role as a hub for regional trade. Dynamism in these services, but also in construction, is expected to offset the effect of declining production of cotton and other cash crops. After a spike in 2005, inflation is on course to return to the low single digits in 2006. The trade deficit is expected to widen significantly in 
2006 due to higher oil prices and declining exports. The impact on the current account deficit is likely to be partly mitigated by strong growth in remittances. Despite the higher current account deficit, international reserves are expected to remain broadly stable reflecting rising capital inflows, including a five-year government bond issue on the regional market, which was oversubscribed. Direct investment and trade related short-term capital flows are projected to increase alongside growing regional trade.

9. The outlook for 2007 points to continued economic recovery, with real GDP growth conservatively estimated at 3 percent. Inflation is expected to remain subdued, as oil prices stabilize and food prices remain contained. We will remain vigilant about growing external imbalances and adjust our policies if necessary.

\section{Fiscal policy}

10. Updated projections for 2006 show a moderate domestic primary fiscal deficit, somewhat above the small deficit in 2005. The revenue-to-GDP ratio is expected to remain broadly unchanged, with relatively strong customs collection due to higher imports and efforts of the tax administration to recover tax arrears. The wage bill is expected to grow strongly in 2006 and 2007, as the long-lasting wage freeze for civil servants is lifted and as teachers who were employed as contractuals during a long hiring freeze are converted into civil servants and their salaries gradually adjusted to reflect those of other teachers. At the same time, unclassified and off-budget spending is projected to fall in 2006. Capital expenditure financed by our recent regional bond is supporting the upgrading of critical infrastructure, hospitals, water, sanitation, and schools. We also paid a first installment to clear SOTOCO's arrears to cotton farmers and will pay another CFAF 6 billion before the end of 2006. Following years of substantial arrears accumulation, we expect that domestic arrears of the central government will decrease somewhat in 2006. Moreover, we plan to carry over a substantial cushion of deposits into 2007 to continue our capital program and transfers for arrears clearance to cotton farmers.

11. We have submitted to parliament a conservative draft 2007 budget law that supports macroeconomic stability in an election year and avoids the accumulation of domestic arrears. The primary deficit will need to be reduced significantly, as we will not issue any further debt on the regional market, and we will need to retain sufficient contingent resources for possible bank restructuring and external arrears clearance. Tax revenues are expected to grow somewhat faster than nominal GDP, based on our recent and planned reforms of tax and customs. Total domestic expenditures will decline modestly in nominal terms as unclassified spending is cut strongly. Civil servants wages will be increased in line with nominal GDP growth following a 10-year wage freeze. The regularization of contractual teachers will continue to contribute to a rising wage bill, although the total wage bill will remain below the ceiling set by the WAEMU conversion criterion of 35 percent of tax revenue. We intend to settle in full all of SOTOCO's arrears to cotton farmers, with payments in April and September 2007, although the latter payment would be contingent on identifying donor financing.

12. Budget implementation in 2006 and 2007 will require that we take measures to enhance budget transparency, bolster revenue collection, and control expenditure based on 
technical assistance recommendations from the IMF, the World Bank, the AfDB, and the UNDP. We have specified several structural benchmarks under the SMP (Table 2) to this end.

- $\quad$ Regarding revenues, we are bolstering administration through internal and external audit units in both tax and customs, while proceeding with the computerization of customs. Moreover, the state inspector general will conduct a review to certify that after the closure of special bank accounts outside the treasury on May 8, 2006, all revenues collected through September 2006 were transferred to the treasury.

- Regarding expenditure control, we recognize that there is an urgent need to return to orderly procedures for committing, verifying, and paying expenditures in order to avoid arrears and make sure that budget allocations are respected. To this end, after eliminating off-budget spending and significantly reducing unclassified spending, we aim to achieve another large reduction in unclassified spending and the use of exceptional procedures in 2007. To that end, we have included in the draft 2007 budget the necessary lines for all expenditures and we will request IMF technical assistance for public financial management. An international auditor will complete an audit of all domestic debt and arrears, with a view to preparing a strategy for regularizing valid arrears over the medium term (Table 2).

- We aim to strengthen the monitoring of budget execution, where a number of weaknesses exist, partly due to lack of funding and technical capacity. To this end, we will seek additional technical and financial assistance to strengthen capacity and computer systems. We are also working on establishing as soon as possible the national audit court (cour des comptes) as required by WAEMU in order to provide for a regular review of budget execution and the treasury accounts. We have established a coordination unit reporting to the Minister of Finance charged with monitoring the implementation of the SMP and other programs with international institutions in order to facilitate the exchange of information and the coordination of the policy dialogue.

13. As noted above, the precarious situation of the banking sector has required repeated intervention by the government. We recognize that as the main shareholder of large stateowned banks, it is critical for the government to monitor closely their liquidity situation in close coordination with the BCEAO and the regional Banking Commission. We will inform Fund staff in case of liquidity pressures and provide data on a regular basis (Table 2). We are committed to preparing a comprehensive bank restructuring plan during the SMP period, in close consultation with IMF, World Bank, BCEAO, and the regional Banking Commission. The ultimate objective is to find strong private strategic investors and strengthen the banks' balance sheet in line with the requirements of the Banking Commission.

14. Regarding public enterprise, we recognize the importance of addressing the problems of the cotton and phosphate sectors. Financial and strategic audits are expected to be completed in early 2007 (Table 2), which would allow us to launch a sector reform strategy. We will seek financial and technical support from donors and the World Bank for the 
preparation and implementation of this strategy. For the phosphate sector, we intend to conduct a financial and strategic audit, with the ultimate objective of ensuring that the company is managed by a strong strategic investor and can return to production and exports at full capacity. We are also working toward improving the investment climate. To that end, we are working on a new investment code in line with work done at the regional level. We will also explore avenues for cutting the cost of doing business and streamlining taxation. To this end, we will seek IMF technical assistance on tax policy.

\section{Preparation of a medium-term strategy for economic growth and poverty alleviation}

15. A medium-term strategy that enjoys broad popular support is needed to guide Togo's policymakers in defining and implementing pro-growth and poverty-reducing macroeconomic policies. We are therefore updating Togo's Interim Poverty Reduction Strategy Paper (I-PRSP) - adopted by the government in November 2004 - in a broad consultative process with members of the unity government, members of civil society, and international organizations. It will describe priority structural and social programs for the next three years and specify external financing needs. It will contain an updated assessment of the dimensions and causes of poverty in Togo, and discuss potential sources of economic growth.

16. The implementation of the medium-term strategy will require extensive support from donors and multilaterals. During the SMP period, we intend to reengage with our development partners, with an initial focus on technical assistance and capacity building. We will also initiate discussions with creditors on mechanisms for clearing Togo's large external arrears ahead of a possible resumption of financial assistance. Starting a new PRGF arrangement is a strategic priority for the country, as we strive to restore confidence in sound governance and macroeconomic management, which could help attract investment and set conditions for sustained economic growth. It would also open the way for urgently needed comprehensive debt relief.

\section{Program monitoring}

17. The SMP covers nine months from October 1, 2006, through June 30, 2007. Quantitative and structural benchmarks are shown in Tables 1 and 2, based on definitions in the attached Technical Memorandum of Understanding. Structural benchmarks focus on budget reform, revenue administration, expenditure management, banking sector reform, and public enterprise reform. Quarterly quantitative benchmarks are based on cumulative changes from year-end 2005 (since end-September 2006 data have not yet been confirmed with Fund staff) and include:

- a floor on the domestic primary fiscal balance;

- a floor on fiscal revenues;

- a ceiling on net domestic financing to government;

- a zero ceiling on the accumulation of domestic arrears;

- a ceiling on the accumulation of external arrears to official creditors; and 
- a zero ceiling on new nonconcessional external debt contracted or guaranteed by the government.

18. A first review of the SMP will assess performance relative to year-end 2006 quantitative targets and relative to structural benchmarks through end-February 2007. A second review of the SMP will assess performance relative to end-June 2007 quantitative and structural benchmarks.

19. We intend to request approval of a PRGF arrangement in the second half of 2007 contingent on: (i) meeting the SMP targets through end-June 2007; (ii) obtaining financing assurances from donors; and (iii) reaching understandings on external arrears clearance with official creditors.

Table 1. Togo: Quantitative Benchmarks Under the Staff-Monitored Program

October 1, 2006-June 30, 2007

(Billions of CFA francs; cumulative changes from Dec. 31, 2005)

\begin{tabular}{|c|c|c|c|c|}
\hline \multirow[b]{3}{*}{ Domestic primary balance (floor) $1 /$} & \multirow{2}{*}{\multicolumn{3}{|c|}{$\frac{\text { Dec. } 2006 \text { Mar. } 2007 \text { June } 2007}{\text { SMP targets }}$}} & \multirow{3}{*}{\begin{tabular}{r}
\multicolumn{1}{c}{ Dec. 2007} \\
Indicative targets \\
-24.5
\end{tabular}} \\
\hline & & & & \\
\hline & -19.3 & -21.8 & -26.3 & \\
\hline Total revenue (floor) & 185.9 & 230.9 & 280.9 & 386.0 \\
\hline Arrears on external debt to official creditors (ceiling) & 30.0 & 35.4 & 45.8 & 62.3 \\
\hline Domestic payments arrears (ceiling) 2/ & 0.0 & 0.0 & 0.0 & 0.0 \\
\hline Net domestic financing (ceiling) $3 /$ & 27.9 & 31.3 & 37.6 & 23.0 \\
\hline $\begin{array}{l}\text { Central government contracting or guaranteeing of } \\
\text { nonconcessional external debt (ceiling) }\end{array}$ & 0.0 & 0.0 & 0.0 & 0.0 \\
\hline
\end{tabular}

1/ Excluding grants and foreign-financed project spending.

2/ Changes in the stock.

$3 /$ Including financing through the regional market. 
Table 2. Structural Benchmarks Under the Staff-Monitored Program

October 1, 2006-June 30, 2007

\begin{tabular}{|c|c|c|}
\hline Category & Structural benchmarks & Date \\
\hline \multirow[t]{2}{*}{$\begin{array}{l}\text { Budget reform and } \\
\text { transparency }\end{array}$} & $\begin{array}{l}\text { - Submit to IMF staff the preliminary audit report of domestic government } \\
\text { debt and arrears, and review the findings. }\end{array}$ & Feb. 2007 \\
\hline & $\begin{array}{l}\text { Close expenditure commitments for } 2006 \text { budget by end-November } \\
2006 \text { and finish issuance of payment authorizations by end-December } \\
2006 \text {. }\end{array}$ & Dec. 2006 \\
\hline $\begin{array}{l}\text { Expenditure } \\
\text { management }\end{array}$ & $\begin{array}{l}\text { Provide monthly data on expenditure based on exceptional payment } \\
\text { orders and limit those without prior budgetary line indication for the } \\
\text { period Jan-June } 2007 \text { at } 6 \text { percent of total expenditure. }\end{array}$ & June 2007 \\
\hline \multirow[t]{2}{*}{$\begin{array}{l}\text { Revenue } \\
\text { administration }\end{array}$} & $\begin{array}{l}\text { Issue decree on tax administration that sets up an external tax audit } \\
\text { service and an internal audit unit. }\end{array}$ & Feb. 2007 \\
\hline & $\begin{array}{l}\text { - Make advanced computer software (SYDONIA++) operational in } \\
\text { customs administration. }\end{array}$ & April 2007 \\
\hline \multirow[t]{2}{*}{ Banking sector } & $\begin{array}{l}\text { Establish a mechanism for the Minister of Finance to monitor liquidity of } \\
\text { state-owned } \mathrm{BTCl} \text { and UTB on a daily basis. Alert staff about any } \\
\text { liquidity pressures. Provide staff with disaggregated liquidity data on a } \\
\text { regular basis, as indicated in the TMU. }\end{array}$ & $\begin{array}{l}\text { Continuous from } \\
\text { Dec. } 2006\end{array}$ \\
\hline & $\begin{array}{l}\text { Design a comprehensive time-bound restructuring plan for } \mathrm{BTCl} \text { and } \\
\text { UTB in coordination with Fund banking experts, the World Bank, and the } \\
\text { regional banking commission. }\end{array}$ & June 2007 \\
\hline \multirow[t]{2}{*}{$\begin{array}{l}\text { Public enterprise } \\
\text { reforms }\end{array}$} & $\begin{array}{l}\text { - Complete financial audit of SOTOCO by February } 2007 \text { and the strategic } \\
\text { audits by April } 2007 \text {. }\end{array}$ & April 2007 \\
\hline & - Launch financial and strategic audit of phosphate sector. & June 2007 \\
\hline
\end{tabular}




\section{TECHNiCAL MEMORANDUM OF UNDERSTANDING}

December 21, 2006

1. This Technical Memorandum of Understanding (TMU) defines the quantitative benchmarks for Togo's staff-monitored program from October 1, 2006 to June 30, 2007. The benchmarks for end-December 2006, end-March 2007, and end-June 2007 are presented in Table 1 of the Memorandum of Economic and Financial Policies (MEFP) dated December 21, 2006, attached. This TMU also sets the deadlines for reporting data to IMF staff for program-monitoring purposes.

\section{DEFINITION OF TERMS}

2. For the purpose of this technical memorandum, the following definitions of "debt," "government," "payments arrears," and "government obligations" will be used:

(a) As specified in Point 9 of the Guidelines on Performance Criteria with Respect to Foreign Debt adopted by the Executive Board of the IMF on August 24, 2000, debt will be understood to mean a current, that is, not contingent, liability created under a contractual arrangement through the provision of value in the form of assets (including currency) or services, and which requires the obligor to make one or more payments in the form of assets (including currency) or services, at some future point(s) in time; these payments will discharge the principal and/or interest liabilities incurred under the contract. Debts can take a number of forms, the primary ones being as follows: (i) loans, that is, advances of money to the obligor by the lender made on the basis of an undertaking that the obligor will repay the funds in the future (including deposits, bonds, debentures, commercial loans, and buyers' credits) and temporary exchanges of assets that are equivalent to fully collateralized loans, under which the obligor is required to repay the funds, and usually pay interest, by repurchasing the collateral from the buyer in the future (such as repurchase agreements and official swap arrangements); (ii) suppliers' credits, that is, contracts where the supplier permits the obligor to defer payments until some time after the date on which the goods are delivered or services are provided; and (iii) leases, that is, arrangements under which property is provided that the lessee has the right to use for one or more specified period(s) of time that are usually shorter than the total expected service life of the property, while the lessor retains the title to the property . For the purpose of the guideline, the debt is the present value (at the inception of the lease) of all lease payments expected to be made during the period of the agreement, excluding those payments that cover the operation, repair, or maintenance of the property. Under the definition of debt set out above, arrears, penalties, and judicially awarded damages arising from the failure to make payment under a contractual obligation that constitutes debt are debt. Failure to make payment on an obligation that is not considered debt under this definition (e.g., payment on delivery) will not give rise to debt. 
(b) Government refers to the central government of the Republic of Togo; it does not include any political subdivision, the central bank, or any government-owned entity with a separate legal personality.

(c) External payments arrears are external payments due but not paid.

(d) Domestic payments arrears consist of (i) the Treasury float, including shortterm notes outstanding; (ii) utility invoices for which the payment order has not yet been issued; (iii) arrears on wages and pensions for which the payment order has not yet been issued.

(e) Government obligation is any financial obligation of the government verified as such by the government (including any government debt that is covered by an agreement with its creditors).

\section{QUanTITATIVE BENChMARKS}

\section{A. Domestic Primary Balance}

\section{Definition}

3. The domestic primary fiscal balance is defined as the difference between (i) the government's fiscal revenue and (ii) total fiscal expenditure, net of interest and current and capital expenditure financed by donors. The deficit in the periods from end-December 2005 to end-December 2006, end-March 2007, and end-June 2007, respectively, will not exceed the amounts indicated in Table 1 attached to the MEFP. The source of the data is the fiscal reporting table (TOFE) prepared monthly by the Economic Directorate of the Ministry of Finance. The data provided by the Economic Directorate will be considered authoritative in the context of the program.

\section{Reporting deadlines}

4. The detailed data on the domestic primary fiscal balance will be reported monthly within eight weeks of the end of the month.

\section{B. Net Domestic Financing}

\section{Definition}

5. Net domestic financing of the government is defined as the sum of (i) net bank credit to the government and (ii) net nonbank domestic financing of the government, including government securities issued in CFA francs on the WAEMU regional financial market that are not held by Togolese commercial banks. Domestic financing in the periods from end-December 2005 to (i) end-December 2006, (ii) end-March 2007, and (iii) end-June 2007, respectively, will not exceed the amounts indicated in Table 1 of the MEFP. 
6. Net bank credit to the government is equal to the balance of claims and debts of the government vis-à-vis national banking institutions. Claims of the government include balances of the Togolese Treasury, deposits of the Treasury with the central bank, deposits of the Treasury with commercial banks (excluding deposits of other government entities, such as autonomous agencies and projects), escrow accounts, and CNSS deposits with commercial banks. Government debt to the banking system includes central bank financing, commercial bank lending (including government securities held by commercial banks), and deposits held with the CCP.

7. The target for end-December 2006 is based on the change in the stock of net bank credit to the government from December 31, 2005; the quarterly targets for end-March and end-June 2007 are based on the cumulative change from end-December 2005.

8. Net nonbank domestic financing includes: (i) the change in the stock of government securities issued in CFA francs on the WAEMU regional financial market not held by Togolese commercial banks; (ii) the change in the deposit accounts of Treasury correspondents; and (iii) the change in miscellaneous deposit accounts at the Treasury and accounts for fines and penalties pending distribution.

9. Net bank credit to the government and the amount of Treasury bill and bond issues in CFA francs on the WAEMU regional financial market are calculated by the BCEAO and net nonbank financing of the government is calculated by the Togolese Treasury. Their figures will be considered authoritative in the context of the program. The data are reported in the TOFE prepared monthly by the Economic Directorate of the Ministry of Finance. The assumption by the government of bank claims on the economy during the program period is excluded from the definition of net domestic financing, while the amortization by the government of such claims is included.

\section{Reporting deadlines}

10. The data on net domestic financing of the government will be reported monthly within eight weeks of the end of the month.

\section{Total Revenue}

\section{Definition}

11. Total fiscal revenue includes tax and nontax revenue, and the revenue of the special accounts and autonomous agencies. The data are calculated by the revenue collection agencies (régies financières) and are reported in the TOFE prepared monthly by the Economic Directorate of the Ministry of Finance. 
12. The increase in revenue in the periods from end-December 2005 to (i) end-December 2006, (ii) end-March 2007, and (iii) end-June 2007, respectively, will be at least equal to the amounts indicated in Table 1 of the MEFP.

\section{Reporting deadlines}

13. These data will be reported monthly to the IMF within four weeks of the end of the month.

\section{Domestic Payments Arrears}

\section{Definition}

14. The net accumulation of domestic payments arrears, defined in paragraph 2(d) above, for the periods from end-December 2005 to (i) end-December 2006, (ii) end-March 2007, and (iii) end-June 2007, respectively, will not exceed the cumulative amounts indicated in Table 1 attached to the MEFP. The government undertakes to accumulate no further domestic payments arrears on the government financial debt, as defined in paragraph 2(e) above. The source of the data on domestic payments arrears is the Treasury for the Treasury float and the Economic Directorate for other arrears. Data on the change in arrears will be reported in the TOFE prepared monthly by the Economic Directorate of the Ministry of Finance.

\section{Reporting deadlines}

15. The data on the stock, accumulation (including changes in Treasury balances outstanding), and repayment of domestic payments arrears will be reported monthly within eight weeks of the end of the month.

\section{E. Arrears on External Debt to Official Creditors}

\section{Definition}

16. Government debt consists of the stock of debt held or guaranteed by the government. Under the program, accumulation of external payments arrears on the government debt will not exceed the amounts indicated in Table 1 of the MEFP for the periods from end-December 2005 to (i) end-December 2006, (ii) end-March 2007, and (iii) end-June 2007, respectively. No payments arrears will be incurred on Treasury bills and bonds issued in CFA francs on the WAEMU regional financial market, or on debt covered by agreements between the government and its creditors. The data source will be the Directorate of Public Debt.

\section{Reporting deadlines}

17. Data on the stock, accumulation, and repayment of external payments arrears will be reported monthly within six weeks of the end of the month. 


\section{F. Nonconcessional External Debt Contracted or Guaranteed by the Government}

\section{Definition}

18. The government undertakes not to contract or guarantee any external debt with an initial term of one year or more that has a grant element of less than 35 percent.

Nonconcessional debt is by definition all debt with a grant element of less than 35 percent. The concessionality of loans with a maturity of at least 15 years will be calculated using a discount rate based on the average of the OECD's published commercial interest reference rates (CIRR); for loans with a maturity of less than 15 years, the average CIRR over six months is used.

19. This benchmark applies not only to debt as defined in point 9 of the Guidelines on Performance Criteria with Respect to Foreign Debt adopted by the Executive Board of the IMF on August 24, 2000, but also to any obligation contracted or guaranteed for which no value has been received. However, this benchmark does not apply to reschedulings in the form of new loans, or to Treasury bills or bonds in CFA francs issued on the WAEMU regional financial market.

\section{Reporting deadlines}

20. The details on any government external loan will be reported monthly within six weeks of the end of the month. This rule will also apply to guarantees granted by the government.

\section{Structural Benchmarks}

21. This section elaborates on the structural benchmarks shown in Table 2 of the MEFP.

a. Submit to IMF staff the preliminary audit report of domestic government debt and arrears, and review the findings (February 2007). The report should indicate the amounts of domestic debt and arrears broken down by main categories. The authorities should coordinate with Fund staff to provide comments on the draft report to the auditor and to identify any follow-up actions.

b. Close expenditure commitments for 2006 budget by end-November 2006 and finish issuance of payment authorizations by end-December 2006 (December 2006). All expenditure commitments (engagements) should be terminated by end-November 2006 (except for salaries, project spending, and debt service) and all 2006 budget payment authorizations (ordonnancements) should be sent to the Treasury by end-December 2006 . The actual payments (réglements) by the Treasury related to the 2006 budget commitments should be completed by the end of the complementary period (période complémentaire), by end-February 2007.

c. Provide monthly data on expenditure based on exceptional payment orders and limit those without prior budgetary line indication for the period Jan.-June 2007 at 6 percent of total expenditure(June 2007). Exceptional payments orders include all payment orders 
sent directly to the Treasury without a payment authorization or express payment order sent to the directorate of finance (ordres de paiements sans télégramme lettre). Total expenditure includes all domestically financed spending. Data requirements are in paragraph 23 e of the TMU. Fund technical assistance staff have recommended several measures that could be considered to help achieve the intended reduction in exceptional payments: (i) for all spending lines (allocation budgétaire) a credit of 25 percent of the annual budget allocation should be opened at the beginning of each quarter; (ii) payment orders (ordres de paiements) should be executed through simplified procedure (procédure simplifiée), including ex-ante authorization (visa) of the department of financial control (control financier), and should normally be executed within three days from the reception of the payment order; (iii) emergency procedures (procédures d'urgence) should be avoided and petty cash funds (regies d'avances) used instead; and (iv) the directorate of finance (direction générale des finances) should be informed on a monthly basis by the Treasury on payments authorization and orders received and settled, and those not yet settled under the current budget.

d. Issue decree on tax administration that sets up an external tax audit service and an internal audit unit (February 2007). The external audit unit should be in charge of conducting controls to ensure that the tax declarations follow the tax code. The internal audit unit should be in charge of ensuring that amount paid by the taxpayers to the collecting agent and the tax receipts deposited with the customs and tax administration are reconcilable. The deadline relates to the signing of the decree.

e. Make advanced computer software (SYDONIA++) operational in customs administration (April 2007). The computer software should be usable in the main five customs offices (headquarters, the offices at the port and airport, and the two main border offices). Adequate human and financial resources should be available for the operation of the system.

f. Establish a mechanism for the Minister of Finance to monitor liquidity of state-owned BTCI and UTB on a daily basis. Alert staff about any liquidity pressures. Provide staff with disaggregated liquidity data on a regular basis, as indicated in the TMU (continuous from December 2006). The monitoring mechanism should ensure that the Minister of Finance has access to daily information and is alerted in case of liquidity pressures, while the day-to-day monitoring could be delegated to others, including the national branch of the BCEAO. See paragraph 27 of the TMU for reporting requirements.

g. Design a comprehensive time-bound restructuring plan for BTCI and UTB in coordination with Fund banking experts, the World Bank, and the regional banking commission (June 2007). The restructuring of the banking sector should take into account recommendations of a forthcoming IMF technical assistance mission, which will assess the soundness of the banking sector and provide recommendations and options for restructuring BTCI and UTB. The plan should be discussed with IMF staff, World Bank staff, and the regional supervisor. The plan should include a time table for its implementation. The deadline refers to the submission of a draft strategy paper to IMF staff. 
h. Complete financial audit of SOTOCO by February 2007 and the strategic audits by April 2007 (April 2007). The financial audit should be based on the terms of reference for the study on the cotton sector in Togo titled "Stratégie de réforme sectorielle de la filière cotonnière du Togo, Audit des dettes et créances de la SOTOCO vis-à-vis de tous es fournisseurs : diagnostic organisationnel et proposition de reformes institutionnelles", Part 1 titled: "Audit de la situation financière de la filière coton au 31 décembre 2005 et analyse détaillée des comptes de résultats et flux de campagne". The auditor's preliminary report on this part should be sent to IMF staff by end-February 2007. The final report of the financial audit and a draft report for the second part of the study on the restructuring of the cotton sector ("Plan de restructuration progressive de la filière"), should be sent to IMF staff by end-April 2007.

i. Launch financial and strategic audit of phosphate sector (June 2007). This includes preparing terms of reference in consultation with Fund staff and World Bank staff and publishing a competitive tender by end-June 2007. 


\section{Additional Information for Program Monitoring}

\section{A. Real Sector}

22. The government will report to Fund staff:

a. the monthly disaggregated consumer price indices, within four weeks of the end of each month;

b. the national accounts, within six months of the end of the year;

c. any revision to the national accounts.

\section{B. Government Finance}

23. The government will report to Fund staff:

a. tax and nontax revenue collected by the General Directorate of Taxes: (1) assessments and collections (émissions et recouvrements) of tax revenues; (2) assessments and collections of nontax revenues; (3) a breakdown of collections of taxes and levies in previous years (récouvrements sur excercises antérieurs des impôts et taxes); and (4) a detailed table of payments and offsetting transactions (apurements et compensations); these data will be reported on a monthly basis within four weeks of the end of the month;

b. the statement of direct and indirect taxes assessed and collected by the Customs Administration; these data will be reported on a monthly basis within four weeks of the end of the reference month;

c. monthly data on execution of the general budget/statement of commitments (engagements) and payment authorizations (ordonnancements): current expenditure on goods and services (dépenses de matériels) of ministries and units; these data will be reported on a monthly basis within four weeks of the end of the month;

d. monthly data on the statement of personnel commitments (engagements) and payment authorizations (ordonnancements); these data will be reported on a monthly basis within four weeks of the end of the month;

e. monthly data on payment orders (ordres de paiements) with or without an express payment order sent to the directorate of finance (télégramme lettre) issued by the Treasury, broken down by category of expenditure, within four weeks of the end of the reference month;

f. monthly data on the general balance of the Treasury accounts (balance générale des comptes du Trésor); these data will be reported on a monthly basis within eight weeks of the end of the month;

g. detailed monthly data on revenue and expenditure, and on domestic and external financing, including payments of domestic and external arrears (TOFE); these data will be reported monthly within eight weeks of the end of the month;

h. monthly statement of Treasury payments, cumulative summary statements of monthly payments, and monthly statements of Treasury outstanding balances (restes à payer) (settlement section-section réglement); these data will be reported on a monthly basis within four weeks of the end of the reference month; 
i. detailed monthly statement of the deposit accounts of Treasury correspondents (dépôts des correspondants au Trésor);

\section{Public Investment Program}

24. The government will report to Fund staff:

- monthly data on the implementation of the Public Investment Program (PIP), including a breakdown of the sources of domestic and external financing (by donor and distinguishing grants and loans); these data will be reported on a monthly basis within eight weeks of the end of the quarter.

\section{Public Debt}

25. The government will report to Fund staff:

a. monthly data on disbursements from external sources for budgetary support and projects; these data will be reported on a monthly basis within eight weeks of the end of the quarter;

b. monthly data on external debt service (amounts due and payments made, by creditor and by currency); these data will be reported within four weeks of the end of the reference month;

c. monthly data on the stock of public debt and domestic and external payments arrears; these data will be reported within four weeks of the end of the reference month.

\section{E. Money and Banking}

26. Each month the authorities will report to IMF staff, within eight weeks of the end of each month:

a. comprehensive survey of monetary institutions, central bank survey, survey of depositary corporations, and net government position vis-à-vis the banking system;

b. average lending and borrowing rates of the banking sector.

27. The authorities will send to IMF staff, within four weeks of the end of each month:

a. a table on the change in the required and constituted reserves of the BTCI and UTB held with the BCEAO, on the basis of daily data;

b. the monthly balance sheet (report form DEC 2000) of the BTCI, UTB, and BIA;

c. monthly change in deposits of the BTCI and UTB, by customer type (private and public).

\section{F. Balance of Payments}

28. The government will report to Fund staff: 
a. partial and preliminary annual balance of payments data, within six months of the end of the year in question, and annual balance of payments data within 12 months of the end of the year in question;

b. any revision to the balance of payments data (including services, private transfers, official transfers, capital transactions) as soon as they are revised;

c. monthly data on private transfers, including assessments of rapid funds transfer activities.

\section{G. Structural Reforms and Other Data}

29. The government will report to Fund staff:

a. any study or official report on the economy of Togo, within two weeks of its publication;

b. any decision, order, law, decree, ordinance, or circular with economic or financial implications, as soon as it is published or, at the very latest, once it takes effect. 